\begin{tabular}{|l|l|}
\hline $\begin{array}{l}\text { 2. To: (Receiving Organization) } \\
\text { LMHC Characterization Engineering }\end{array}$ & $\begin{array}{l}\text { 3. From: (Originating Organization) } \\
\text { Characterization Engineering }\end{array}$ \\
\hline $\begin{array}{l}\text { 5. Proj./Prog./Dept/Div.: } \\
\text { Characterization Project }\end{array}$ & $\begin{array}{l}\text { 6. Design Authority/Design Agent/Cog. Engr.: } \\
\text { GP Janicek/BL Coverdell/RN Dale }\end{array}$ \\
\hline
\end{tabular}

8. Originator Remarks:

Supporting document submitted for review and approval prior to release.

11. Receiver Remarks:

\section{Related EDT No.: \\ N/A \\ 7. Purchase Order No.: \\ N/A}

9. Equip/Component No.:

N/A

10. System/Bldg./Facility:

$200 \mathrm{G}$

12. Major Assm. Dwg. No.

N/A

13. Permit/Permit Application No.:

N/A

14. Required Response Date:

ASAP

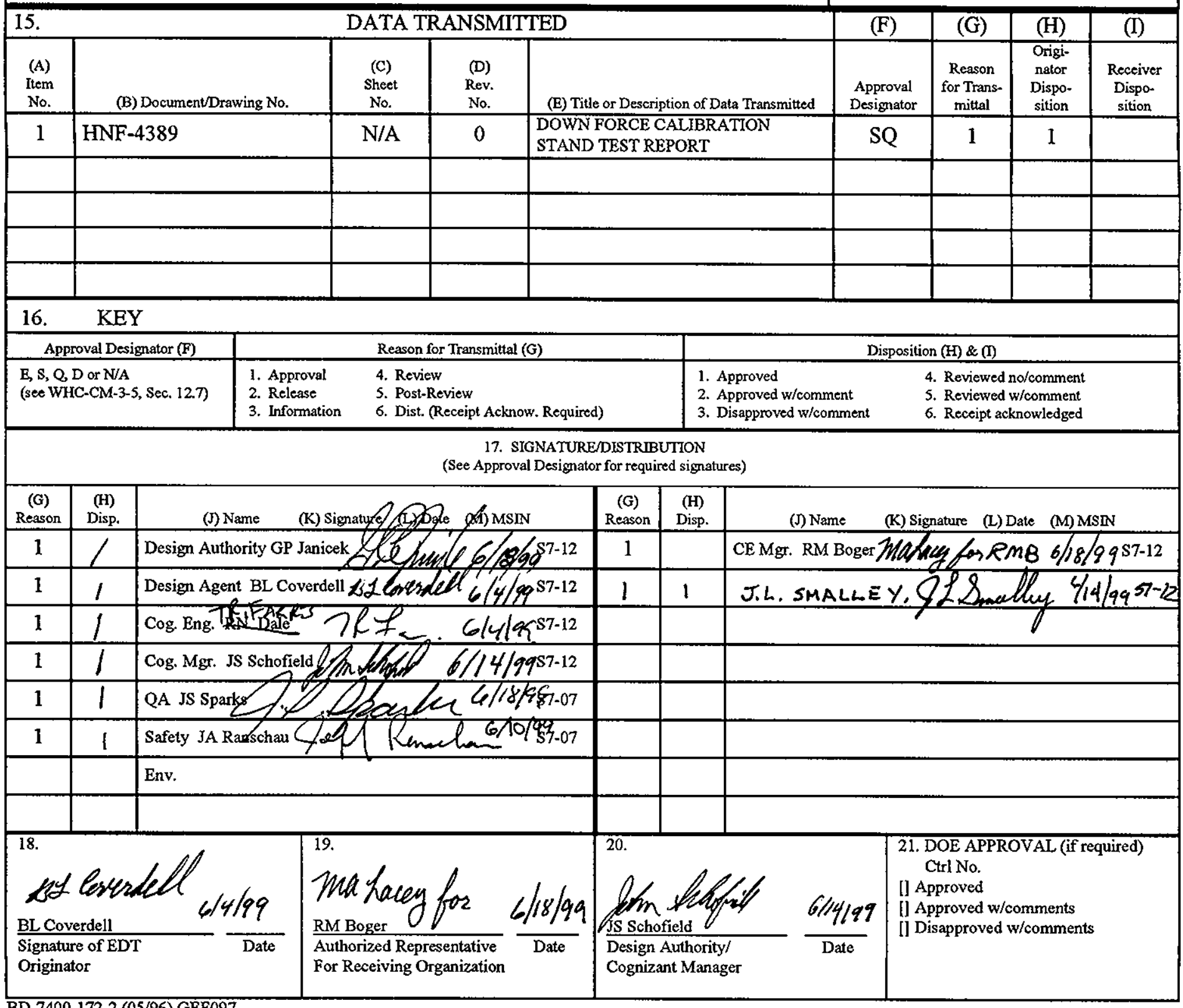




\title{
DOWN FORCE CALIBRATION STAND TEST REPORT
}

\author{
R. M. Boger \\ Prepared by Lockheed Martin Hanford Company \\ 2400 Stevens \\ Richland, WA 99352 \\ U.S. Department of Energy Contract DE-AC06-96RL13200
}

EDT/ECN: 623356

Org Code: 74900

B\&R Code: EW3120074

UC: 2070

Charge Code: $\mathrm{CACN}: 102250 \quad$ COA: $\mathrm{EI00}$

Total Pages: 590

PE $6-21-99$

Key Words: Calibration, Rotary Mode Core Sample Truck (RMCST), Down Force, Drill String, Drill Rig

Abstract: The Down Force Calibration Stand was developed to provide an improved means of calibrating equipment used to apply, display and record Core Sample Truck (CST) down force. Originally, four springs were used in parallel to provide a system of resistance that allowed increasing force over increasing displacement. This spring system, though originally deemed adequate, was eventually found to be unstable laterally. For this reason, it was determined that a new method for resisting down force was needed.

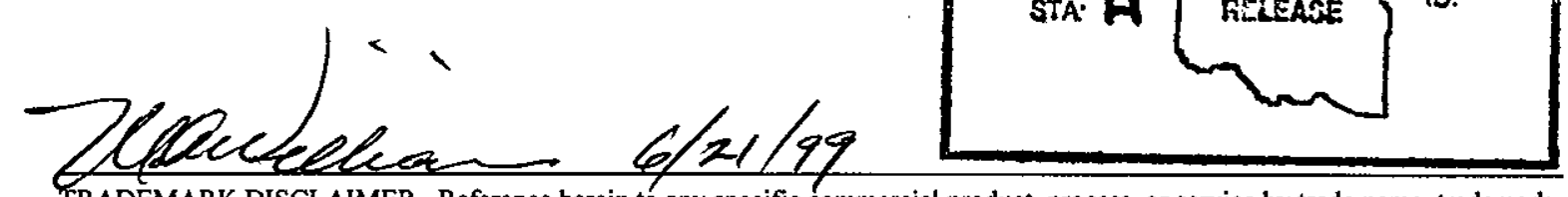

TRADEMARK DISCLAIMER. Reference herein to any specific commercial product, process, or service by trade name, trademark, manufacturer, or otherwise, does not necessarily constitute or imply its endorsement, recommendation, or favoring by the United States Government or any agency thereof or its contractors or subcontractors.

Printed in the United States of America. To obtain copies of this document, contact: Document Control Services, P.O. Box 950, Mailstop H6-08, Richland WA 99352, Phone (509) 372-2420; Fax (509) 376-4989.

\section{Approved for Public Release}




\section{DOWN FORCE CALIBRATION STAND TEST REPORT}

Prepared for Lockheed Martin Hanford Corporation Characterization Engineering Group

By

B. L. Coverdell

COGEMA Engineering Corporation

June 1999 


\section{TABLE OF CONTENTS}

1.0 INTRODUCTION

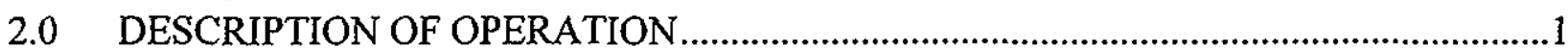

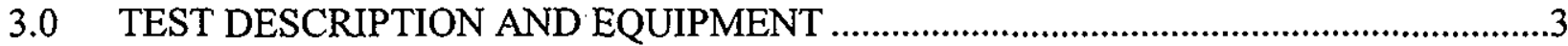

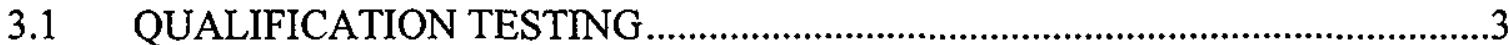

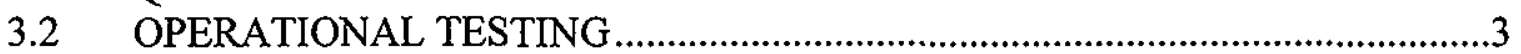

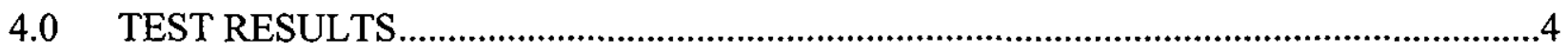

4.1 QUALIFICATION TESTING .......................................................................

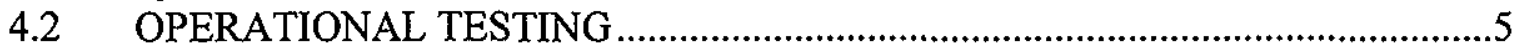

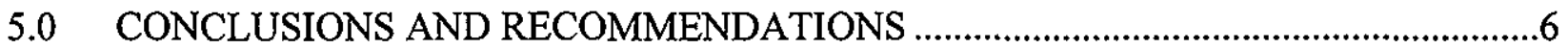

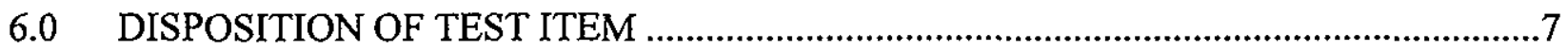

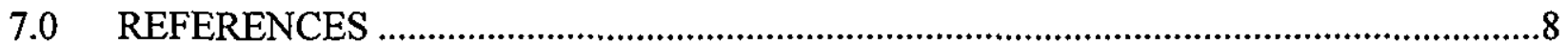

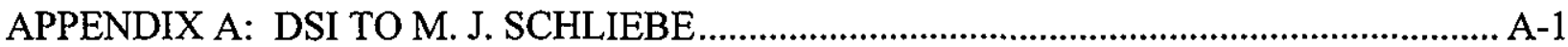

APPENDIX B: TEST PROCEDURE DATA SHEETS ...........................................................

APPENDIX C: TEST DATA AND CALCULATIONS ............................................................

APPENDIX D: DOWN FORCE CALIBRATION STAND TEST PROCEDURE .................... D-1

APPENDIX E: TEST PROCEDURE DATA SHEETS ……………..........................................

\section{TABLE OF FIGURES}

Figure 1: Down Force Calibration Stand ............................................................................. 2

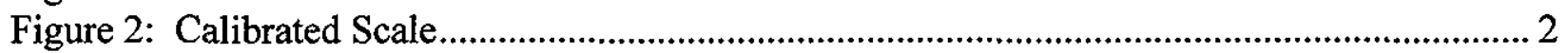

\section{TABLE OF GRAPHS}

Graph 1: Scale and WI-1 Force vs. Theoretical Down Force (Push Mode) ..................................... 5

Graph 2: Scale and WI-1 Force vs. Theoretical Down Force (Rotary Mode) .................................... 6 


\subsection{INTRODUCTION}

In order to calibrate equipment used to determine and display down force on core sample trucks some type of down force calibration stand is required. This calibration stand must be able to allow approximately eleven inches of drill string displacement as the drill string down force increases. Originally, four springs were used in parallel to provide a system of resistance that allowed increasing force over increasing displacement. This spring system, though originally deemed adequate, was eventually found to be unstable laterally when loaded.

A new Down Force Calibration Stand was fabricated to provide an improved means of calibrating equipment used to measure, display and record Core Sample Truck (CST) down force. The Down Force Calibration Stand is used to transmit force from the drill string to a calibrated scale while allowing displacement of the drill head.

Testing of the Down Force Calibration Stand was completed using two approaches, both operational tests and qualification tests were completed. Qualification testing of the new Down Force Calibration Stand was completed to ensure that it will give precise, accurate and repeatable results (i.e. no binding will occur in the system). Operational testing was conducted to demonstrate the stability of the calibration stand when used with a CST.

\subsection{DESCRIPTION OF OPERATION}

The down force calibration stand uses a bellows type air spring to provide the required resistance. Four rods are used to support an aluminum plate that is used to secure the top and bottom of the air spring (see Figure 1). Both the top and bottom plates are allowed to move vertically up and down the four rods by the use of linear bearings at all four corners of both plates. The linear bearings allow the spring to expand and contract depending on the applied down force and it also allows movement of a calibrated scale (see Figure 2) that is placed underneath the lower plate. A small thrust bearing is installed on the upper plate. The thrust bearing combined with a cap is used to secure the drill string laterally, resist the down force and allow rotation of the drill string. The total amount of displacement of the air spring and upper plate depends on the pressure in the air spring. The air spring is required to have a minimum of 2.5 psig to 6 psig. During down force calibration the operating pressure is set to 5 psig. For safety reasons, the maximum pressure of $90 \mathrm{psig}$ is limited by a pressure relief valve. 


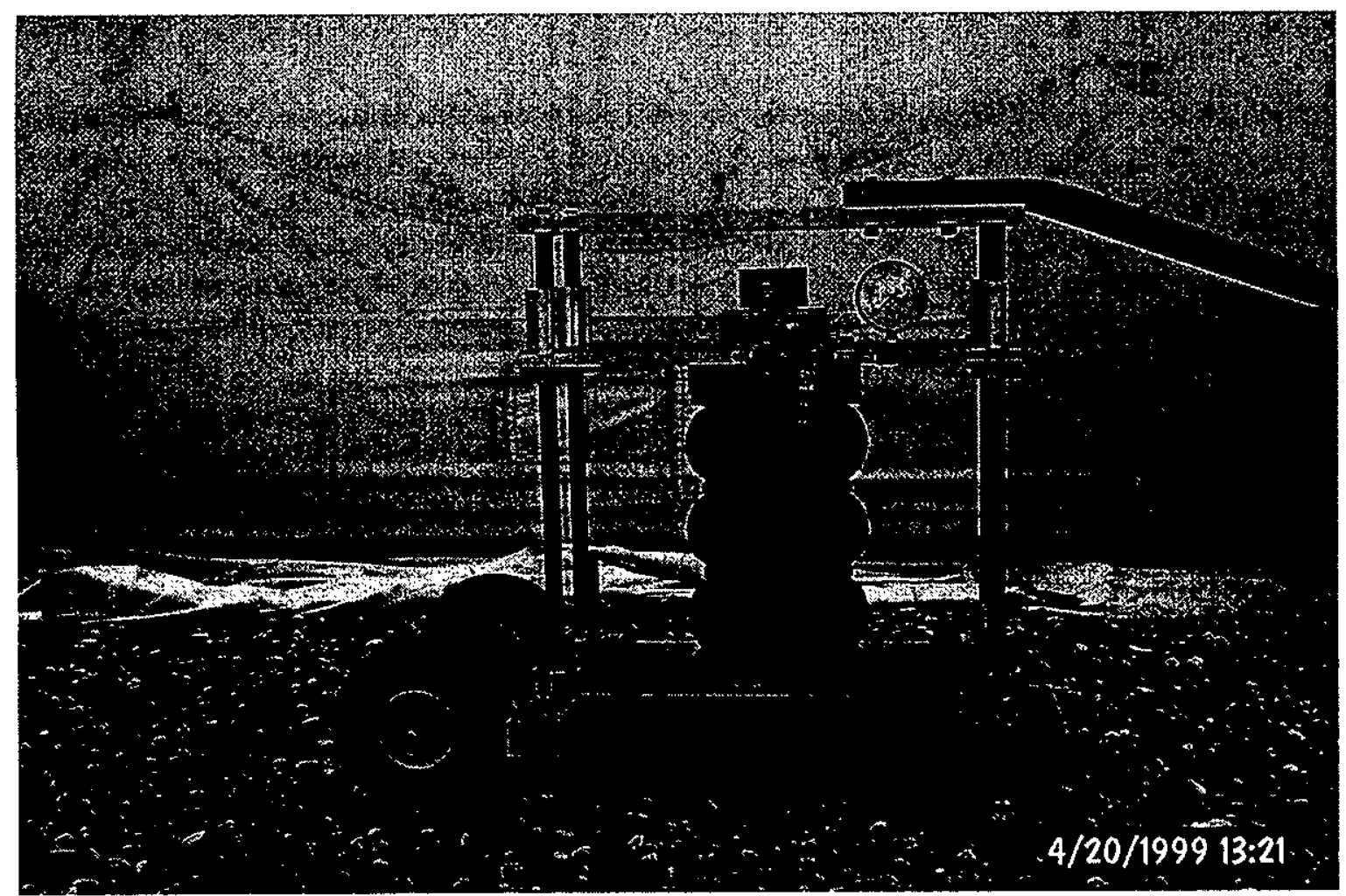

Figure 1: Down Force Calibration Stand

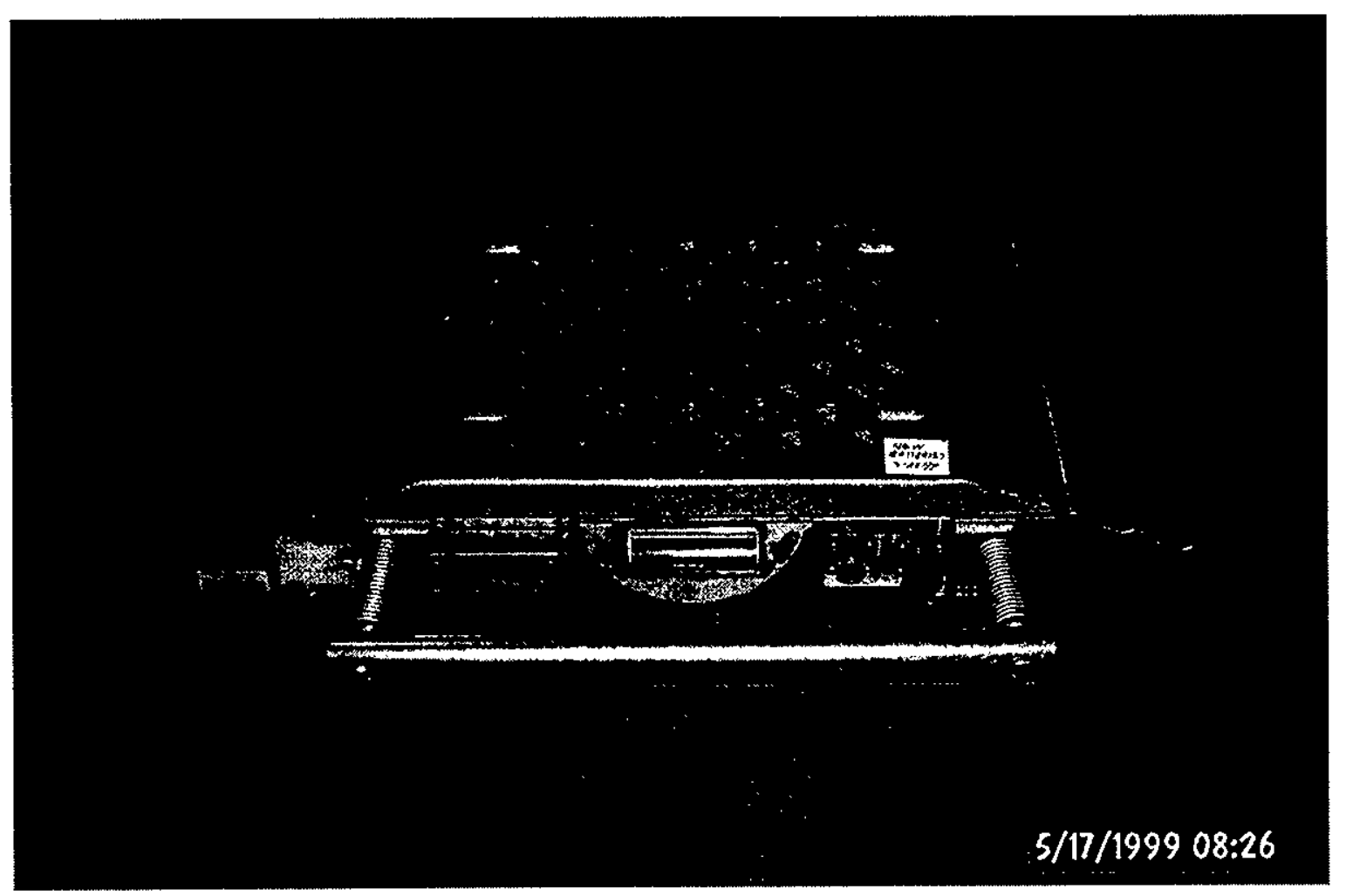

Figure 2: Calibrated Scale 
HNF-4389, Rev. 0

\subsection{TEST DESCRIPTION AND EQUIPMENT}

\subsection{QUALIFICATION TESTING}

Qualification testing of the down force calibration stand was completed using a SATEC Systems, Inc. Universal Testing Machine. This machine can apply up to $120,000 \mathrm{lb}$. of tensile or compressive force and is large enough to allow the Down Force Calibration Stand to fit inside, however, the SATEC is not calibrated. For this reason, the initial test from the test plan (see Appendix A) was to verify that the indicated force by the SATEC Testing Machine matched the applied force on a calibrated scale which was placed inside the SATEC Testing Machine. The calibration date on the scale is $2 / 5 / 99$ and the calibration number is 776-66-01-00 (see Appendix B, Page B-2).

The second qualification test was to add 5 psig to the air spring and a known weight (in this case three $26 \mathrm{lb}$. weights) to the calibration stand and let all the air out of the air spring. This test was performed to ensure early in the qualification testing that the air spring would completely deflate and that no binding of the bearings would occur.

The final qualification tests are all similar the only difference between them is the amount of pressure in the air spring. Each test was to inflate the air spring to $2 \mathrm{psig}, 5 \mathrm{psig}$ or $7 \mathrm{psig} \pm 1 / 2 \mathrm{psig}$ and then add compressive force by the SATEC Testing Machine in increments of $200 \mathrm{lb}$. up to $3000 \mathrm{lb}$. total. After each $200 \mathrm{lb}$. increment, the force indicated by the SATEC and the calibrated scale were recorded. Each test was repeated five times for each pressure, however, the pressure in the air spring was varied from test to test.

\subsection{OPERATIONAL TESTING}

Appendix D contains the operational test procedure used during testing of the down force calibration stand. This test procedure was performed by Characterization Project Operations Maintenance personnel and witnessed by Characterization Engineering personnel. The down force calibration stand was tested in three ways: The first test was to ensure that the stand transmitted a known weight to the scale accurately. The second test was to use a CST to apply down force in push mode only (no rotation of the drill string) up to a maximum down force of $3000 \mathrm{lb}$. The final test was to use a CST to slowly apply down force in rotary mode up to a maximum down force of $1200 \mathrm{lb}$.

The first test used multiple weights which were weighed using a recently calibrated scale. The weights were placed on the Down Force Calibration Stand and then weight readings were taken from the scale. The actual weight of the weights was compared to the transmitted weight as read from the calibrated scale. This was done to ensure that the Down Force Calibration Stand would transmit force without any binding occuring 
causing a loss in transmitted force. This information is recorded on the data sheets in Appendix E, Page E-2.

The second test was completed to ensure that the Down Force Calibration Stand would transmit the down force from a CST in push mode to a calibrated scale in a safe, stable and accurate manner. In push mode, $0 \mathrm{lb}$. to $3000 \mathrm{lb}$. of force on the CST was slowly applied to the top of the Down Force Calibration Stand and as the force was applied data was read from the calibrated scale and WI-1 (Weight Indicator). This data is recorded in Appendix E, Page E-3.

The third test was completed to ensure that the Down Force Calibration Stand would transmit the down force from a CST in rotary mode to a calibrated scale in a safe, stable and accurate manner. In rotary mode, $0 \mathrm{lb}$. to $1200 \mathrm{lb}$ of force was slowly applied to the top of the Down Force Calibration Stand and as the force was applied data was read from the calibrated scale and WI-1.

\subsection{TEST RESULTS}

\subsection{QUALIFICATION TESTING}

The data from Test 1 is contained in Appendix B, Page B-2 and B-5. This data verifies that the compressive force readout of the SATEC Universal Testing Machine corresponds to that of the calibrated scale to which the compressive force is being applied. Appendix $\mathrm{C}$ puts the data from Appendix B in a spreadsheet so statistical calculations could be completed on the data. The deviation between the calibrated scale and the SATEC Universal Testing Machine is calculated for each of the $200 \mathrm{lb}$. increments. The maximum and minimum deviation for the data set was determined to be $22 \mathrm{lb}$. and $1 \mathrm{lb}$. respectively. The overall standard deviation was also calculated for the data set and was determined to be $10.03 \mathrm{lb}$.

For Test 2 three weights were first weighed on the calibrated scale. The three weights were determined to weigh $70 \mathrm{lb} . \pm 10 \mathrm{lb}$. The scale was then inserted into the Down Force Calibration Stand and the weights were placed on top of the air spring top plate. The weight was then read from the calibrated scale and was determined to be $90 \mathrm{lb} . \pm 10 \mathrm{lb}$.

The remaining tests were all similar, only the pressure in the air spring was varied. The pressure in the air spring was varied between $2 \mathrm{psig}, 5 \mathrm{psig}$ and $7 \mathrm{psig}$. This results in different deflections of the air spring given the same loads. Each of three pressure tests was repeated five times randomly. The results of these tests are located in Appendix B and summarized in Appendix C. The maximum and minimum deviation was determined $40 \mathrm{lb}$. and $1 \mathrm{lb}$. respectively. The standard deviation for all fifteen tests was determined to be $10.2 \mathrm{lb}$. (the initial load of $0 \mathrm{lb}$. not considered when computing the standard deviation). 


\subsection{OPERATIONAL TESTING}

The push mode test data is recorded in Appendix E, Page E-3 and E-4 and is displayed in Graph 1. The rotary mode test data is recorded in Appendix E, Page E-5 and is displayed in Graph 2. Actual ${ }_{i, 1}$ represents data from the calibrated scale and Actual $_{\mathrm{i}, 2}$ represents data from weight indicator one.

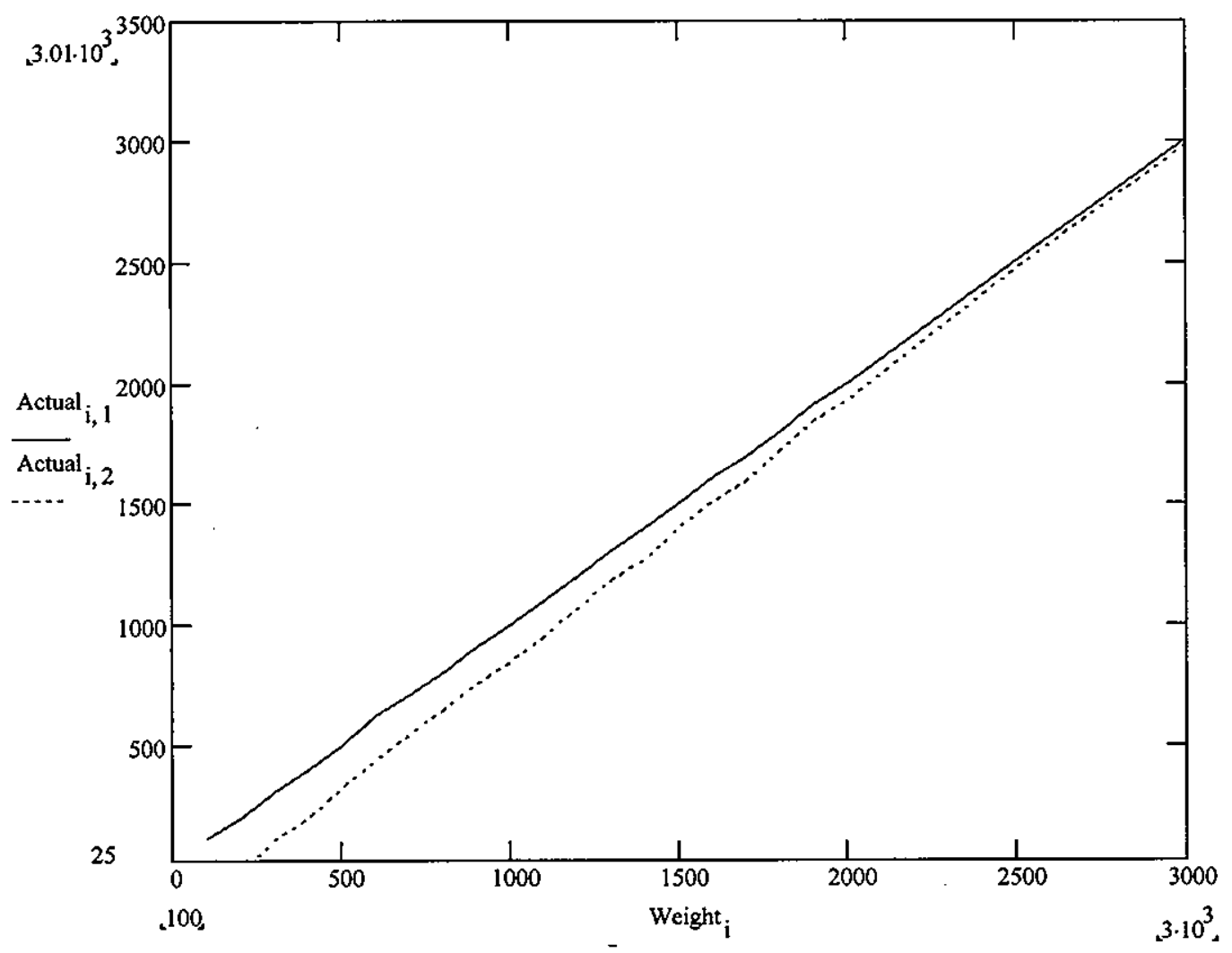

Graph 1: Scale and WI-1 Force vs. Theoretical Down Force (Push Mode) 


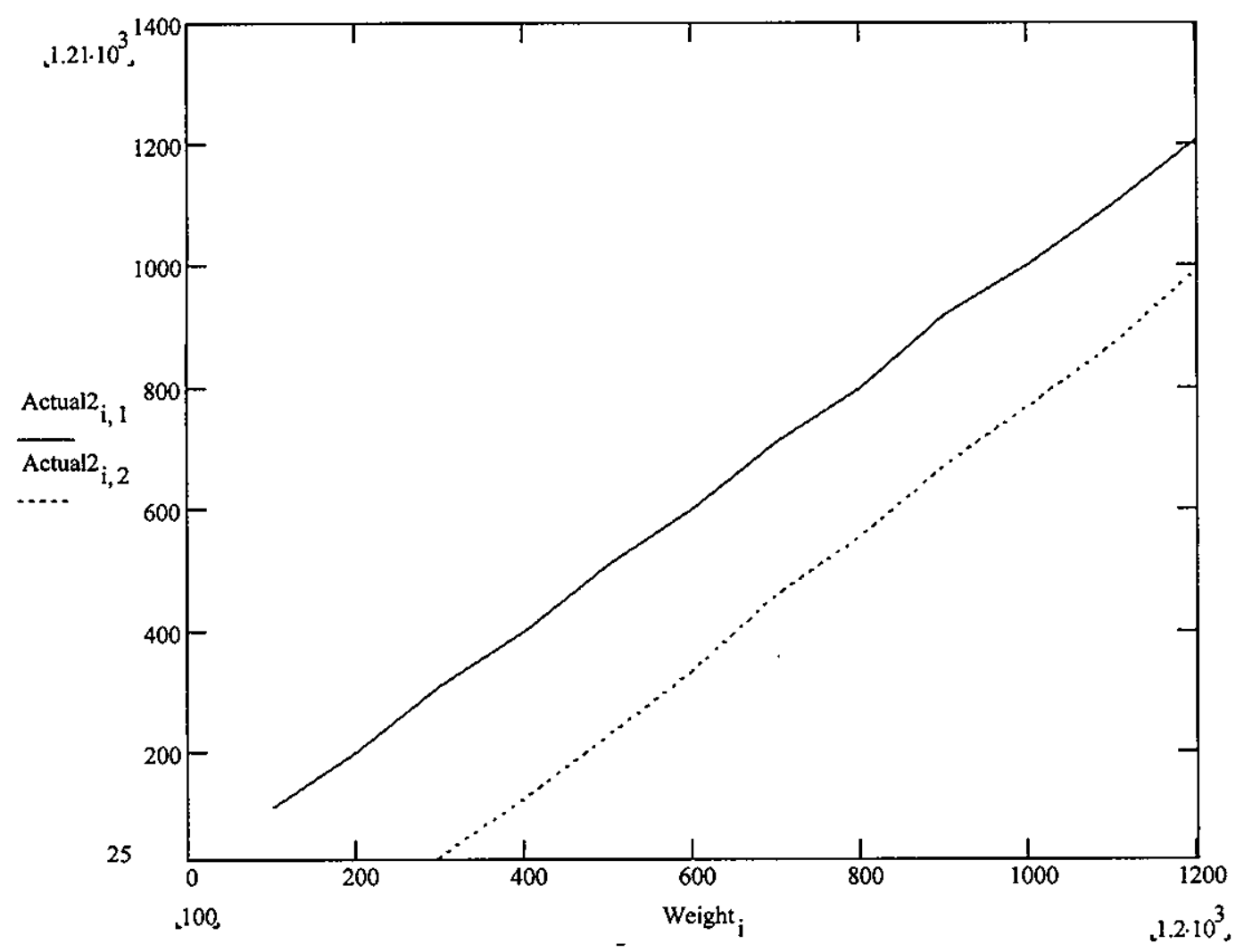

Graph 2: Scale and WI-1 Force vs. Theoretical Down Force (Rotary Mode)

\subsection{CONCLUSIONS AND RECOMMENDATIONS}

The Down Force Calibration Stand completed all qualification and operational testing satisfactory. During qualification testing, minor deviations were noted between the SATEC Universal Testing Machine and the calibrated scale. This is likely due to the calibrated scale's ability to display in only $10 \mathrm{lb}$. increments and its high load rating $(25,000 \mathrm{lb}$.). In addition, a couple readings occurred after the SATEC Universal Testing Machine applied a loading over the expected $200 \mathrm{lb}$. increment. After the overloading occurred, the SATEC was unloaded to the expected loading. This resulted in erroneous readings from either the calibrated scale or the SATEC or possibly both.

Operational testing resulted in the Down Force Calibration Stand being shown adequate for both push mode calibration and rotary mode calibration. The stand remained highly stable throughout all phases of operational testing and no noticeable binding of the stand occurred.

Since the calibrated scale has such a high load rating and that it is only accurate to $\pm 10 \mathrm{lb}$. it is recommended that the calibrated scale be replaced with a new scale. The new scale should have a smaller load rating $(0 \mathrm{lb}$. to $5000 \mathrm{lb}$.). A smaller load rated scale would give more accurate and precise readings for the loads applied during calibration of the CSTs load of $0 \mathrm{lb}$. to $3000 \mathrm{lb}$. 


\subsection{DISPOSITION OF TEST ITEM}

Operational and qualification testing has shown that the Down Force Calibration Stand provides an accurate, stable and safe means of transmitting down force to a calibrated scale in both rotary and push mode. For this reason, the Down Force Calibration Stand is released to perform both push mode and rotary mode calibration of a CST down force equipment. 
HNF-4389, Rev. 0

7.0 REFERENCES

None

Page 8 
HNF-4389, Rev. 0

APPENDIX A: DSI TO M. J. SCHLIEBE

TESTING OF DOWN FORCE CALIBRATION STAND

Page A-1 
DON'T SAY IT — Write It!

TO: M. J. Schliebe

R. M. Boger

G. P. Janicek

R. N. Dale

J. S. Schofield
L6-13

S7-12

S7-12

S7-12

S7-12
DATE: May 10, 1999

FROM: G. P. Janicek

Telephone: $\quad 376-2225$
S7-12

\section{SUBJECT: Testing of Down Force Calibration Stand}

Characterization Engineering requests that the tests listed below be performed on the down force calibration stand per the following statement of work. This work may be charged to CACN 102250.

General Note: Before applying down force to the down force calibration stand, ensure that ball valve is closed.

TEST 1: $\quad$ Verification of Satec down force.

- Record calibration number and last calibration date of truck scale

- Using Satec, apply $200 \mathrm{lbs}$ of down force to the top of the calibrated truck scale. Record readout of Satec and truck scale in data sheet 1.

- $\quad$ Continue applying and recording down force in $200 \mathrm{lb}$ increments up to $3000 \mathrm{lb}$ maximum.

\section{TEST 2:}

- Insert truck scale in down force calibration stand.

- Zero truck scale.

- Inflate down force calibration stand to $5 \mathrm{psig} \pm 1 / 2 \mathrm{psig}$.

- Use a calibrated scale to verify weights to be used in the following step.

- Record air spring inflation height

- $\quad$ Add approximately $50 \mathrm{lb}$. of weights to the top of the upper air spring plate.

- Record the scale weight

- If the indicated scale weight and the calibrated weights match $\pm 10 \mathrm{lbs}$, continue with test.

- $\quad$ Slowly release air spring pressure and let deflate.

- Record final deflated air spring deflection

- Record final indicated scale weight

\section{TEST 3:}

- Verify truck scale reads zero.

- Inflate down force calibration stand air spring to 2 psig $\pm 1 / 2$ psig.

- Using Satec, apply 200 lbs of down force to the top of the calibrated truck scale. Record readout of Satec and truck scale in data sheet 2. 
- Continue applying and recording down force in $200 \mathrm{lb}$ increments up to $3000 \mathrm{lb}$ maximum.

\section{TEST 4:}

- Verify truck scale reads zero.

- Inflate down force calibration stand air spring to $5 \mathrm{psig} \pm 1 / 2 \mathrm{psig}$.

- Using Satec, apply $200 \mathrm{lbs}$ of down force to the top of the calibrated truck scale. Record readout of Satec and truck scale in data sheet 3.

- Continue applying and recording down force in $200 \mathrm{lb}$ increments up to $3000 \mathrm{lb}$ maximum.

\section{TEST 5:}

- Verify truck scale reads zero.

- Inflate down force calibration stand air spring to $7 \mathrm{psig} \pm 1 / 2 \mathrm{psig}$.

- Using Satec, apply $200 \mathrm{lbs}$ of down force to the top of the calibrated truck scale. Record readout of Satec and truck scale in data sheet 4.

- Continue applying and recording down force in $200 \mathrm{lb}$ increments up to $3000 \mathrm{lb}$ maximum. 


\section{Table 1: VERIFICATION OF SATEC DOWN FORCE Inflation Pressure \\ DOWN FORCE READOUT}

Truck Scale (LB)

SATEC (LB) 


\section{Table 2: Down Force Inflation Pressure}

\section{DOWN FORCE}

SATEC

TRUCK SCALE 


\section{Table 3: Down Force Inflation Pressure}

DOWN FORCE

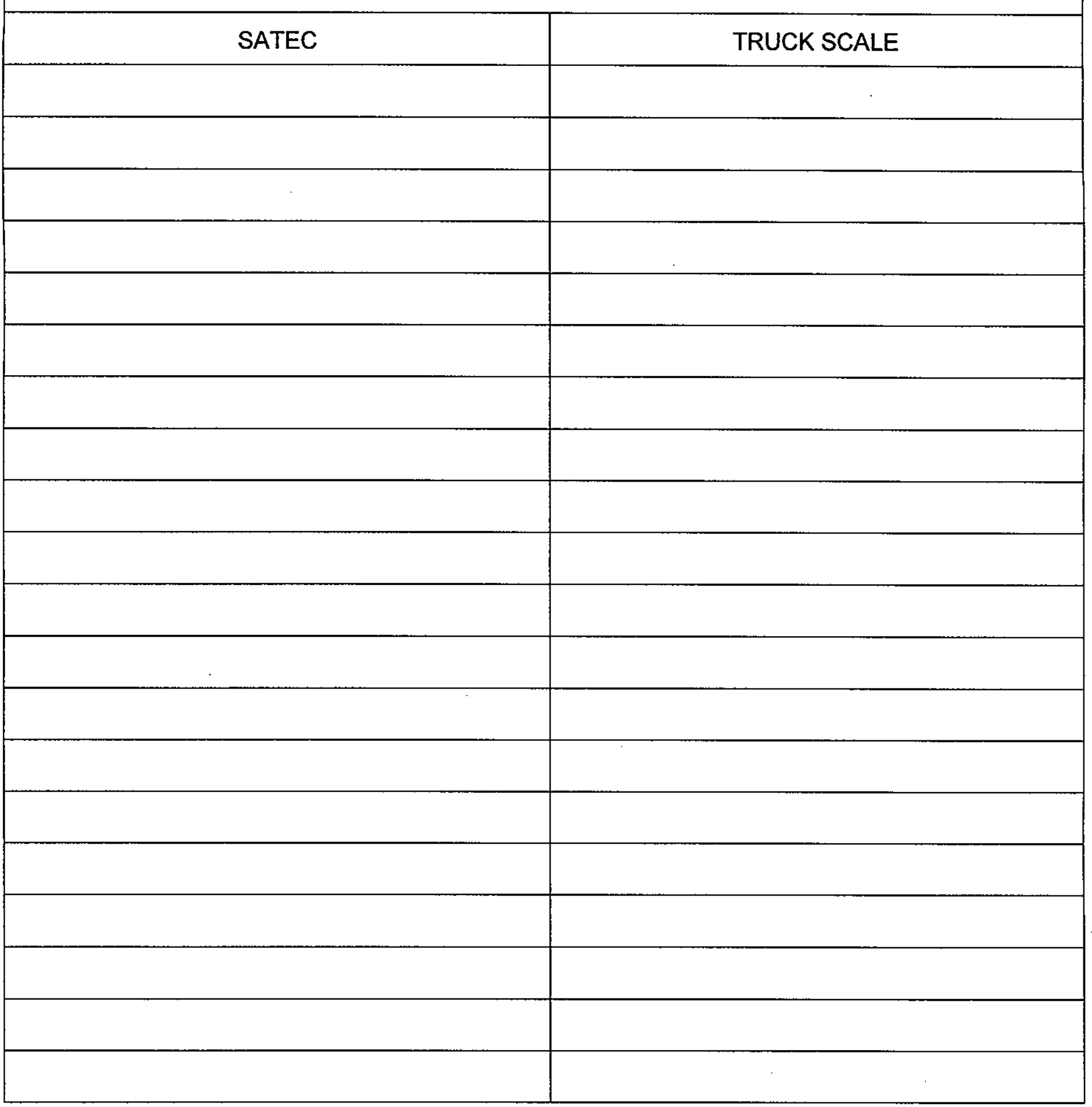




\section{Table 4: Down Force Inflation Pressure} DOWN FORCE

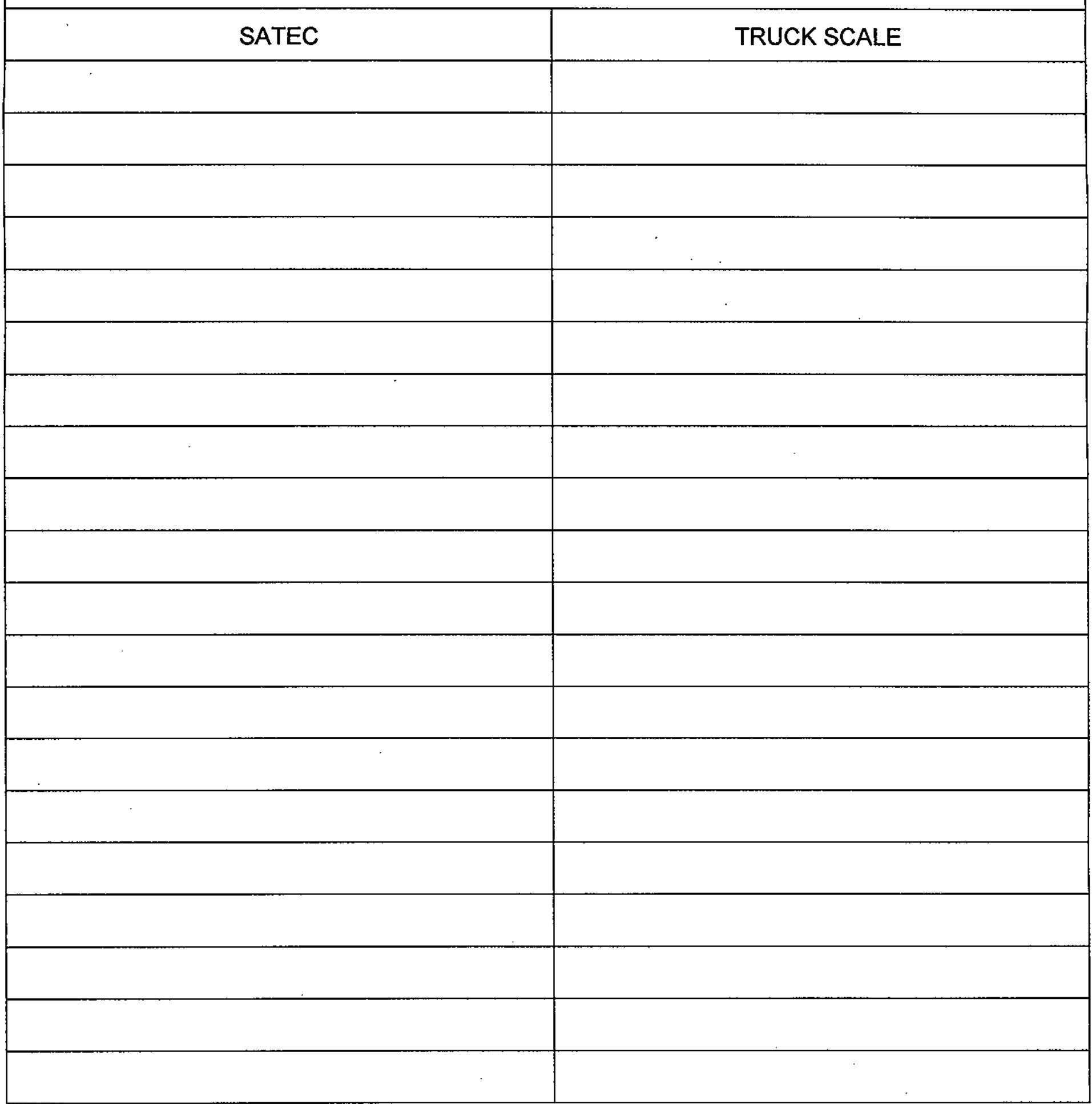


HNF-4389, Rev. 0

APPENDIX B: TEST PROCEDURE DATA SHEETS

Page B-1 
HNF-4389, Rev. 0

DON'T SAY IT - Write It!

TO: M. J. Schliebe L6-13

cc:

S7-12
DATE: $\quad$ May 10, 1999

FROM: G.P. Janicek

Telephone: $\quad 376-2225$
S7-12

$57-12$

S7-12

S7-12

SUBJECT: Testing of Down Force Calibration Stand

Characterization Engineering requests that the tests listed below be performed on the down force calibration stand per the following statement of work. This work may be charged to CACN 102250.

General Note: Before applying down force to down force calibration stand, ensure that ball valve is closed.

TEST 1: Verification of Satec down force.

- Record calibration number and last calibration date of truck scale $2 / 5-199,776-66-$

- Using Satec, apply $200 \mathrm{lbs}$ of down force to the top of the calibrated truck scale. Record $0 /-00$, readout of Satec and truck scale in data sheet 1.

- Continue applying and recording down force in $200 \mathrm{lb}$ increments up to $3000 \mathrm{lb}$ maximum.

\section{TEST 2:}

- Insert truck scale in down force calibration stand.

- Zero truck scale.

- Inflate down force calibration stand to 5 psig $\pm 1 / 2$ psig.

- Use a calibrated scale to verify weights to be used in the following step.

- Record air spring inflation height $71 / 4$ ". Bottrm to Top

- Add approximately $50 \mathrm{lb}$. of weights to the top of the upper air spring plate.

- Record the scale weight $70 \% 90$

- If the indicated scale weight and the calibrated weights match $\pm 10 \mathrm{lbs}$, continue with test.

- Slowly release air spring pressure and let deflate.

- Record final deflated air spring deflection $91 / f^{\prime \prime} / 1.7 \frac{15}{16}$

- Record final indicated scale weight $90^{\#} \sqrt{7}$

TEST 3:

- Verify truck scale reads zero.

- Inflate down force calibration stand air spring to 2 psig $\pm 1 / 2$ psig.

- Using Satec, apply 200 Ibs of down force to the top of the calibrated truck scale. Record readout of Satec and truck scale in data sheet 2 . 
- Continue applying and recording down force in $200 \mathrm{lb}$ increments up to $3000 \mathrm{lb}$ maximum.

\section{TEST 4:}

- Verify truck scale reads zero.

- Inflate down force calibration stand air spring to 5 psig $\pm 1 / 2 \mathrm{psig}$.

- Using Satec, apply $200 \mathrm{lbs}$ of down force to the top of the calibrated truck scale. Record readout of Satec and truck scale in data sheet 3.

- Continue applying and recording down force in $200 \mathrm{lb}$ increments up to $3000 \mathrm{lb}$ maximum.

\section{TEST 5:}

- Verify truck scale reads zero.

- Inflate down force calibration stand air spring to $7 \mathrm{psig} \pm 1 / 2 \mathrm{psig}$.

- Using Satec, apply $200 \mathrm{lbs}$ of down force to the top of the calibrated truck scale. Record readout of Satec and truck scale in data sheet 4.

- Continue applying and recording down force in $200 \mathrm{lb}$ increments up to $3000 \mathrm{lb}$ maximum. 
HNF-4389, Rev. 0

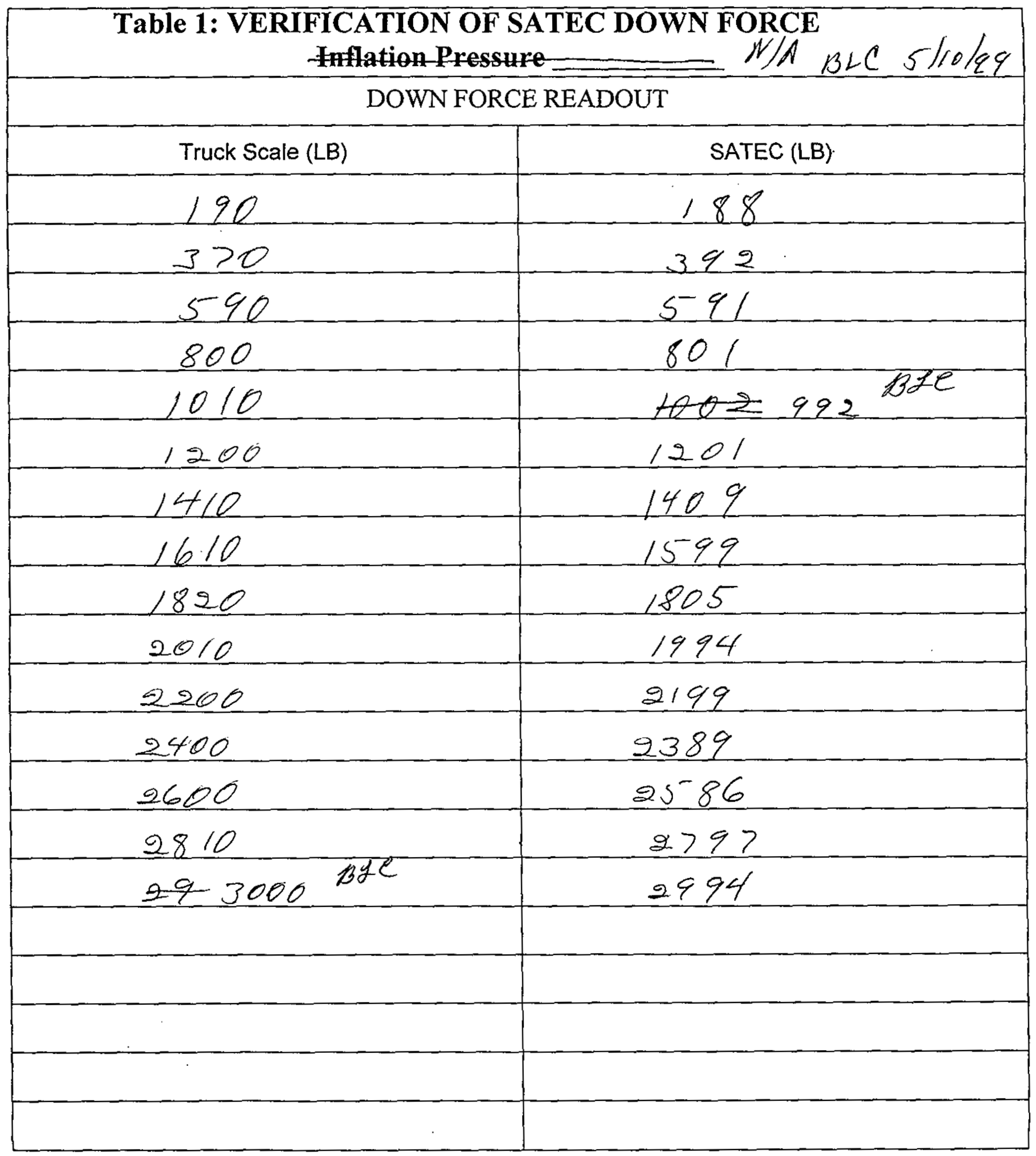

A-3000-723 (01/98)

Page B-4 
HNF-4389, Rev. 0

Test \#2

Repeat

$\begin{array}{ccc}\text { Saitec } & \text { Truck } & \text { dint } \\ 80 & 60 & 8^{\prime \prime} \\ 80 & 60 & 10^{\prime \prime} \\ 80 & 60 & 17^{\prime \prime} \\ 80 & 60 & 19^{\prime \prime} \\ 80 & 60 & 18^{\prime \prime} \\ 80 & 60 & 18^{\prime \prime} \\ 80 & 60 & 19 "\end{array}$

Page B-5 
HNF-4389, Rev. 0

\#)

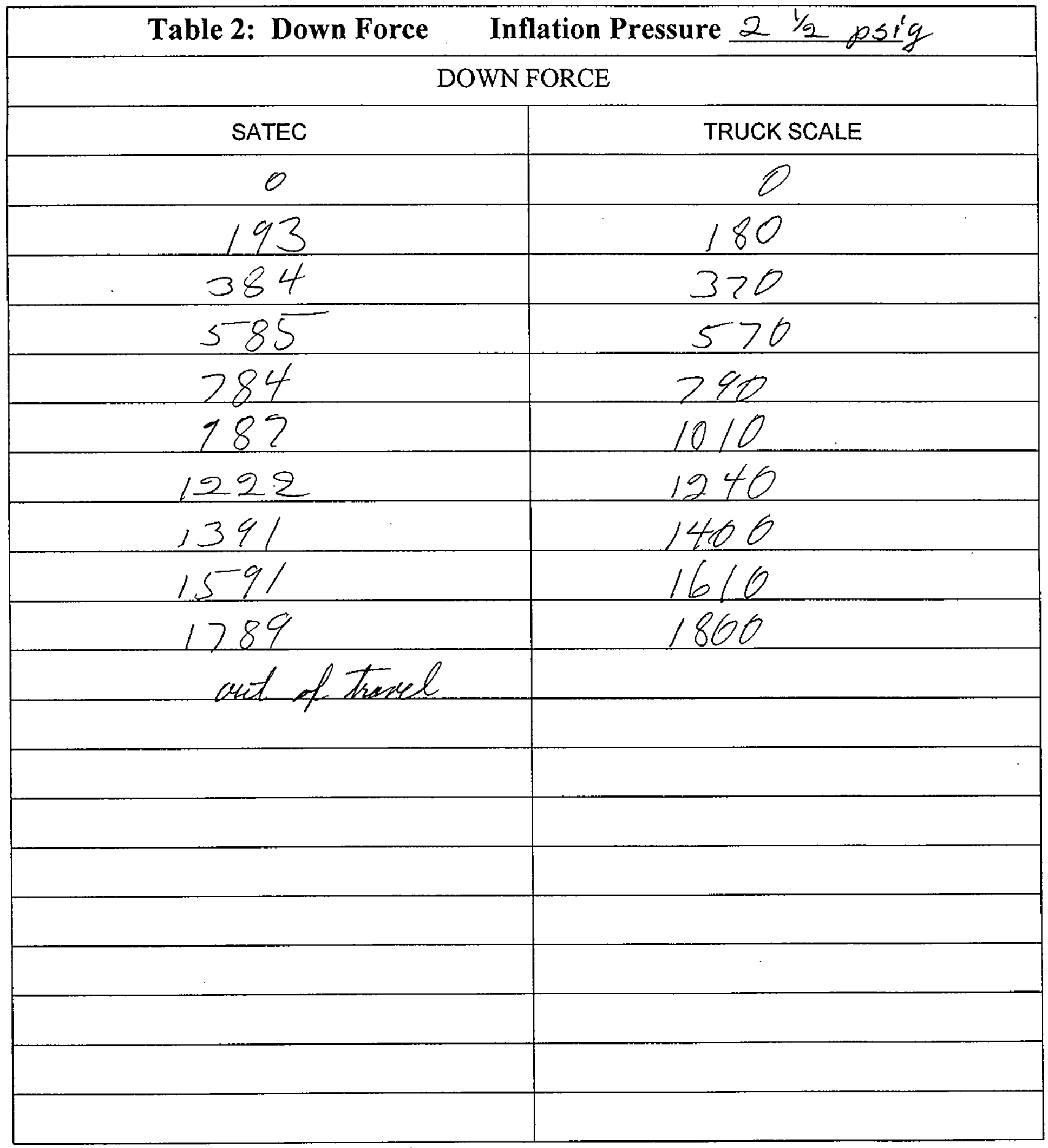

A-3000-723 (01/98)

Page B-6 
HNF-4389, Rev. 0

$\# 2$

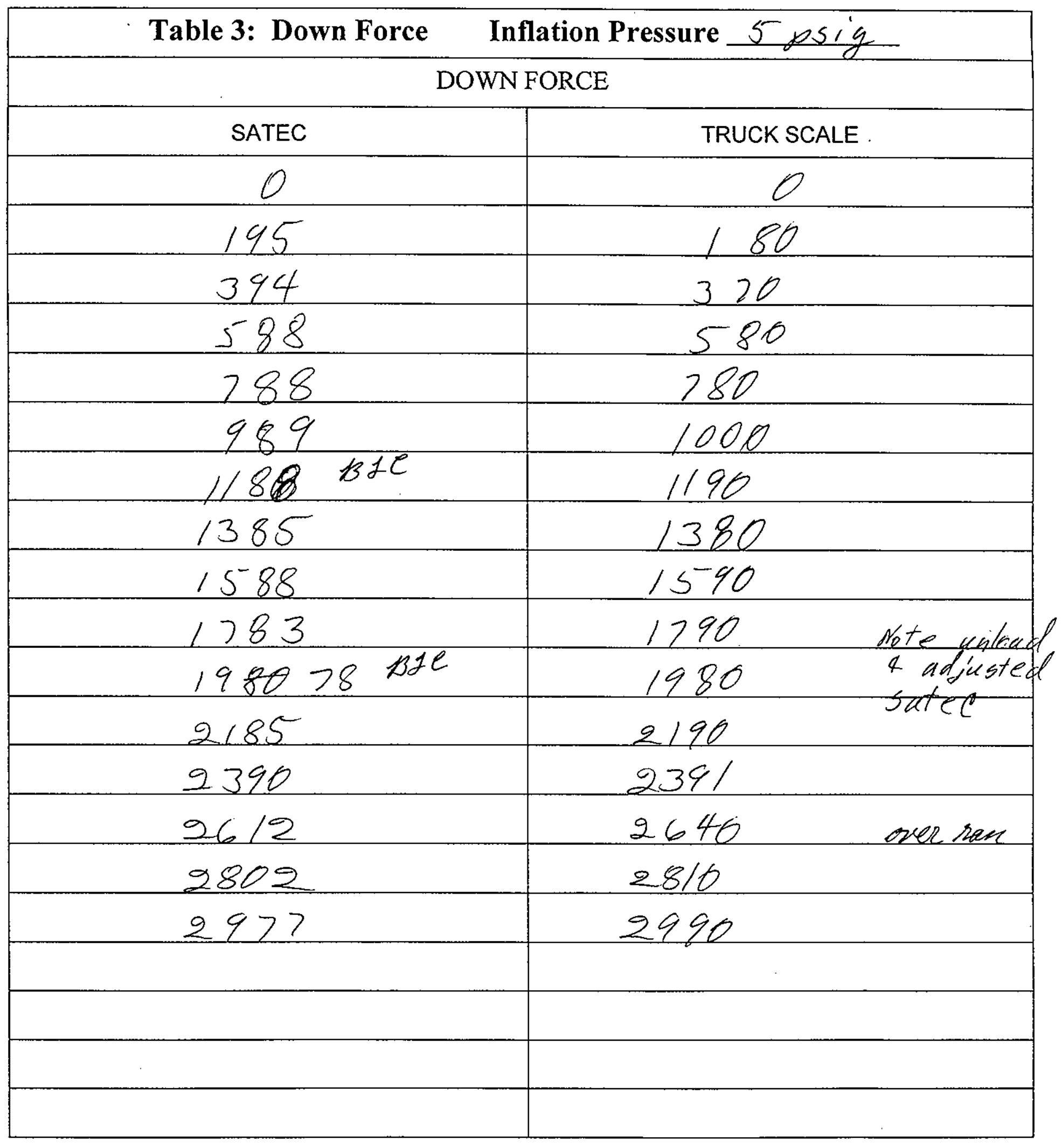

A-3000-723 (01/98)

Page B-7 
HNF-4389, Rev. 0

\#3

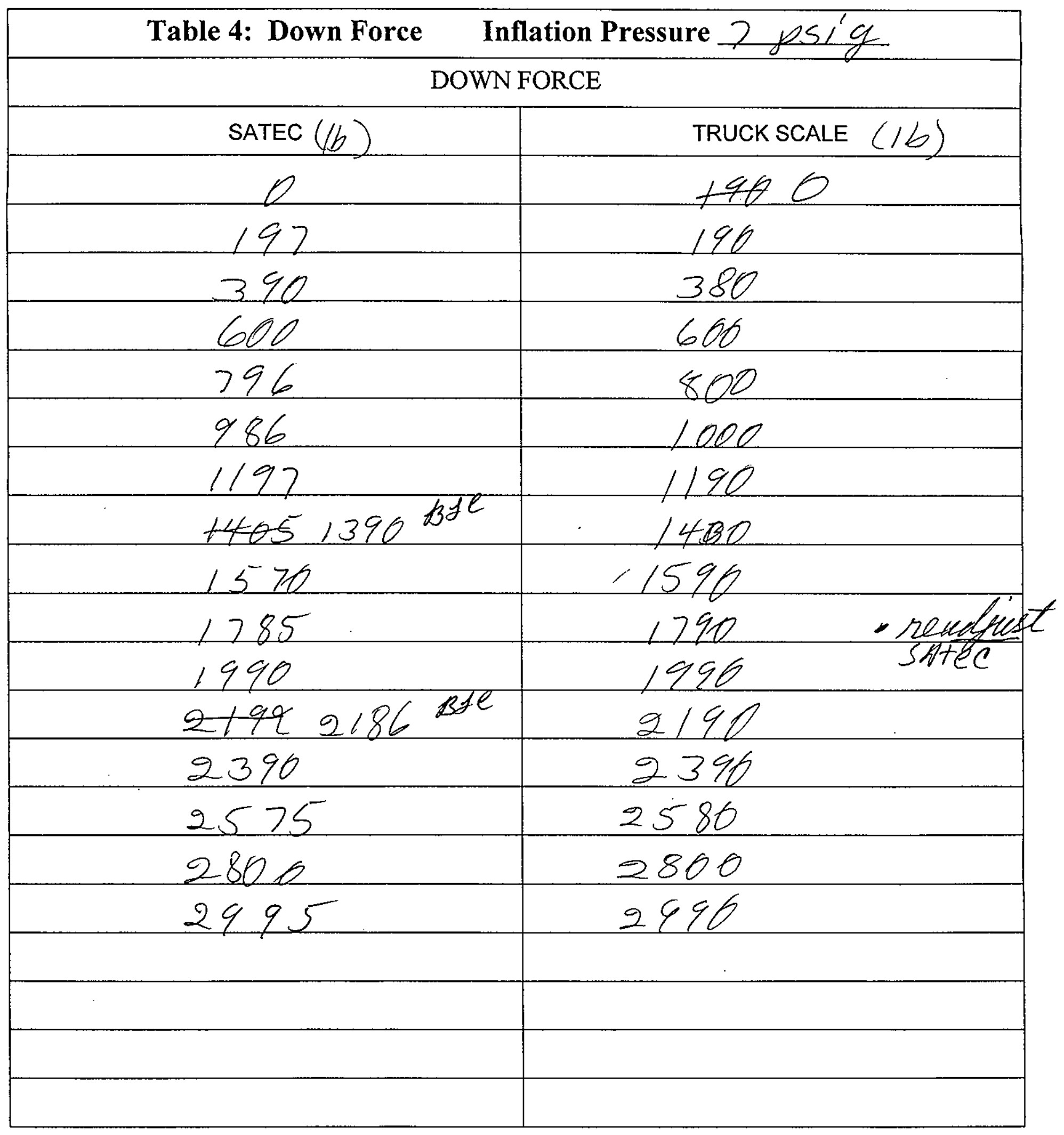

A-3000-723 (01/98)

Page B-8 
HNF-4389, Rev. 0

(4)

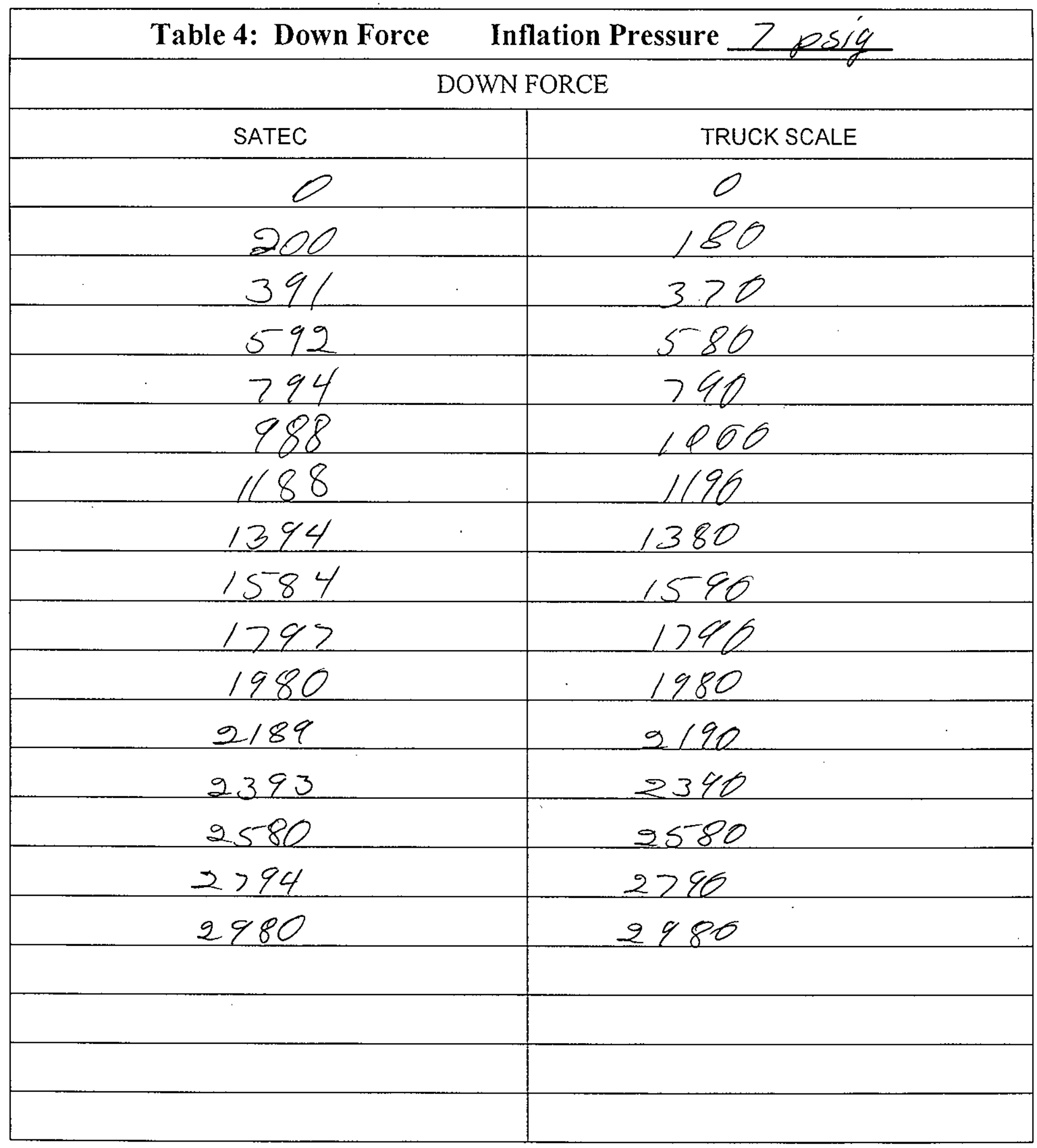

A-3000-723 (01/98)

Page B-9 
HNF-4389, Rev. 0

(5)

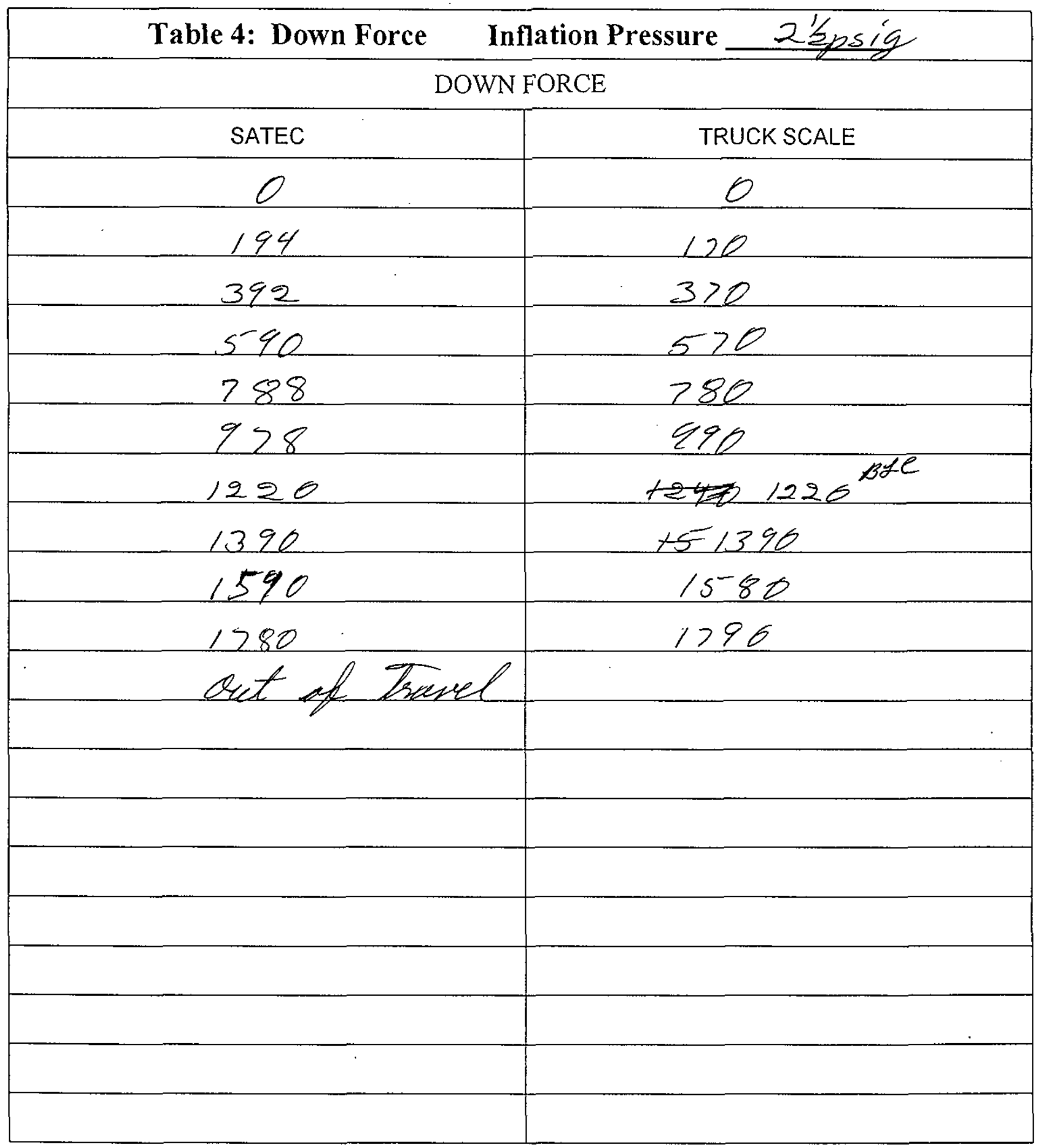

A-3000-723 (01/98)

Page B-10 
HNF-4389, Rev. 0

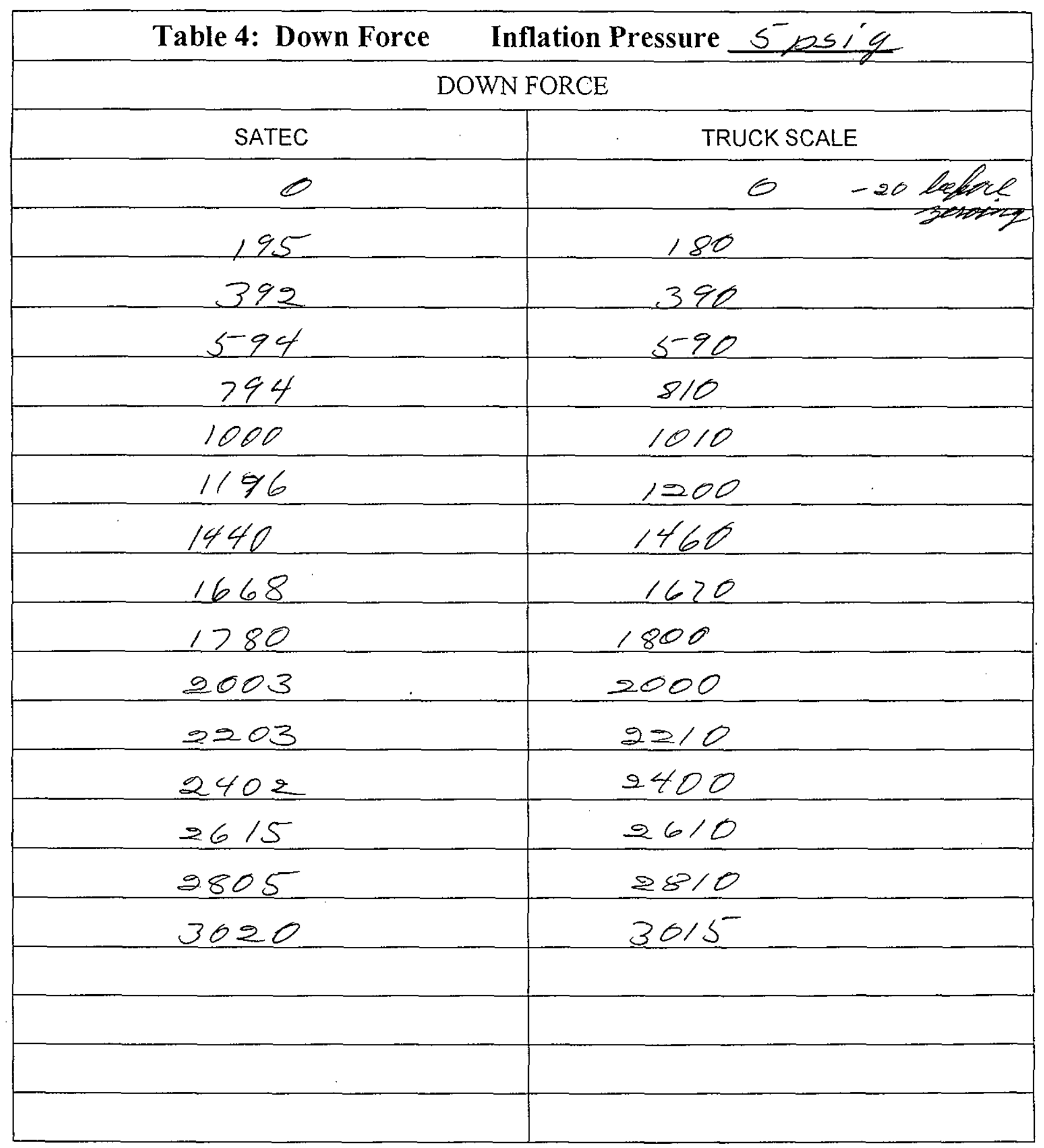

A-3000-723 (01/98)

Page B-11 
HNF-4389, Rev. 0

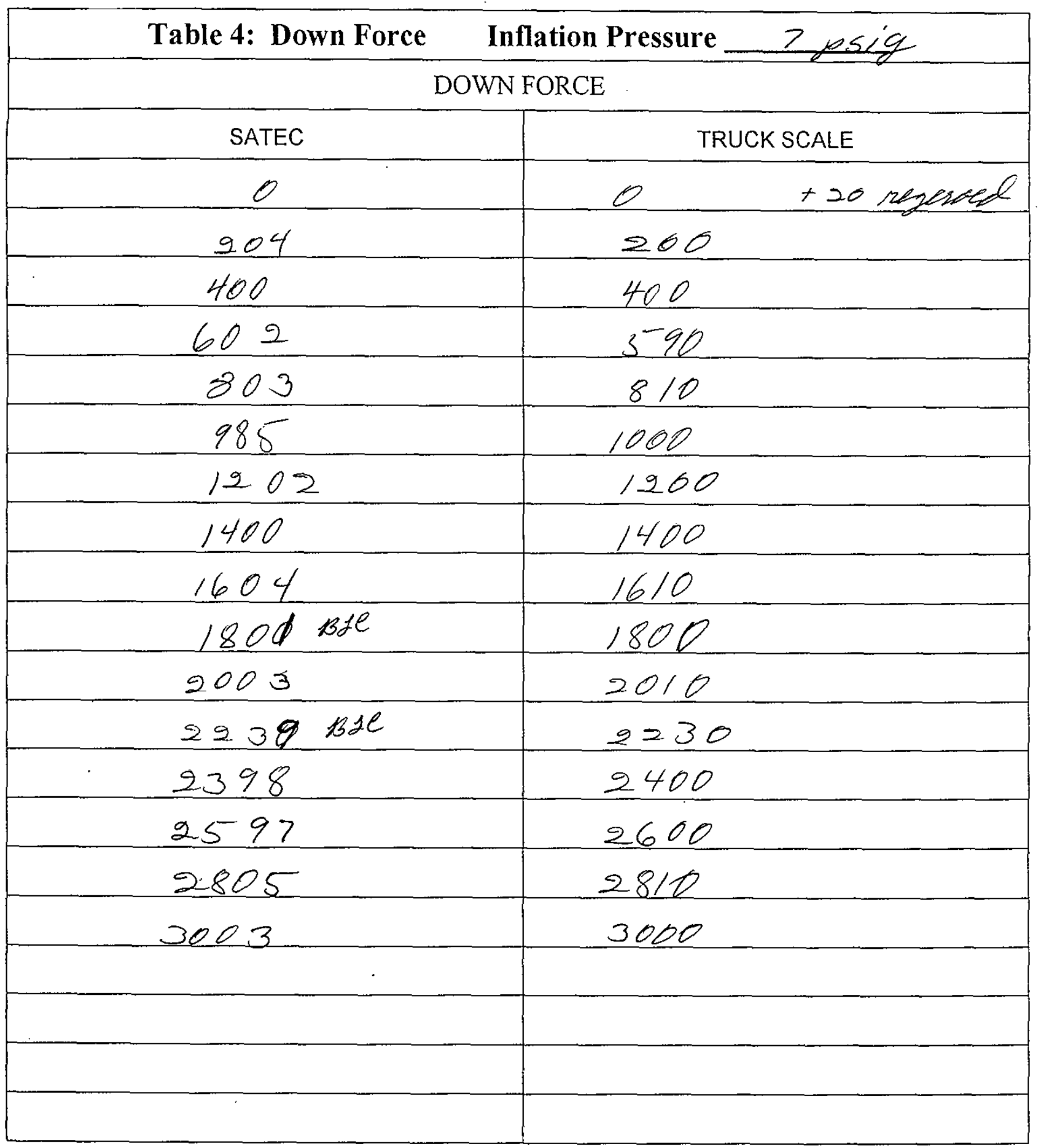

A-3000-723(01/98)

Page B-12 
HNF-4389, Rev. 0

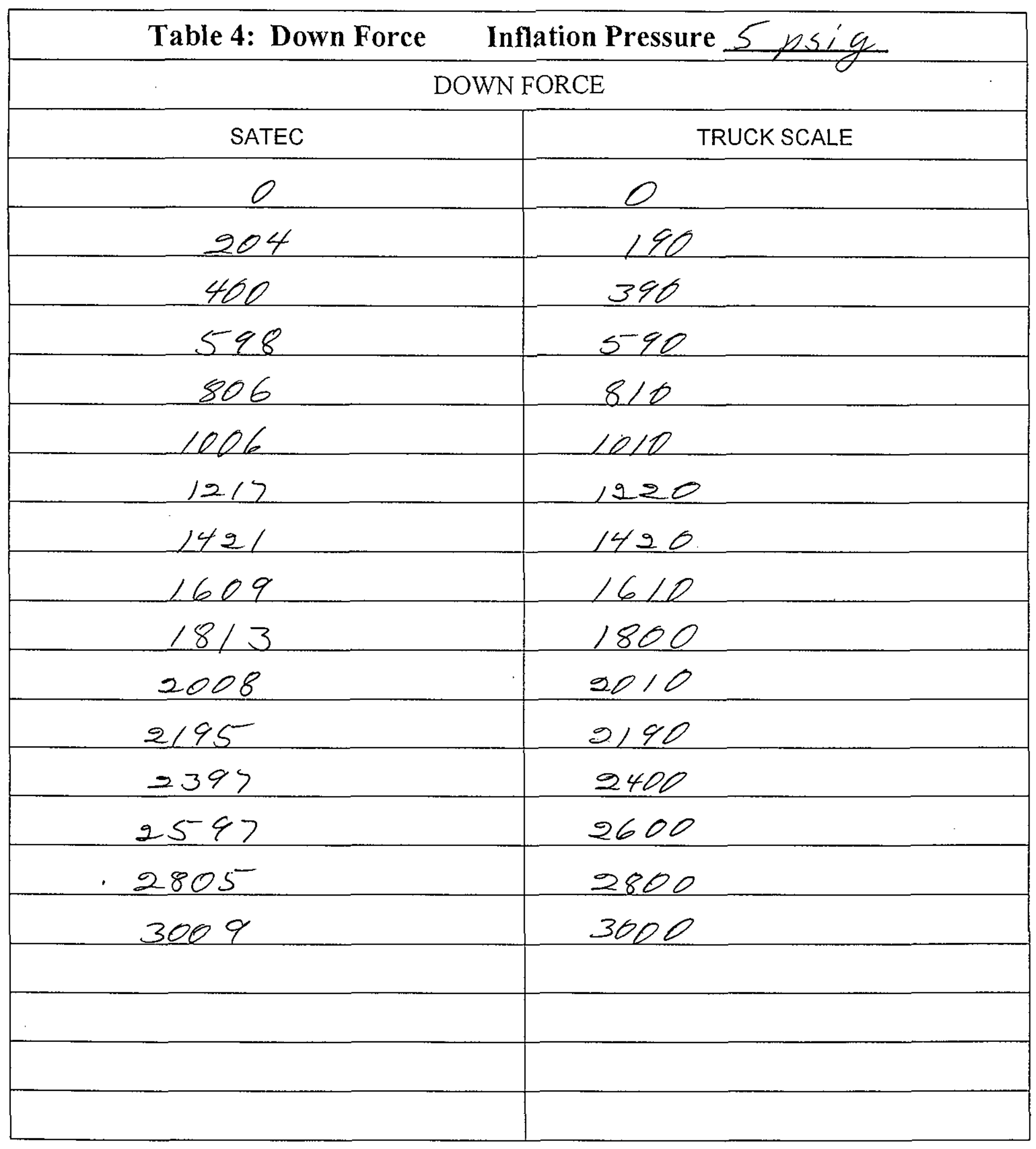

A-3000-723 (01/98)

Page B-13 
HNF-4389, Rev. 0

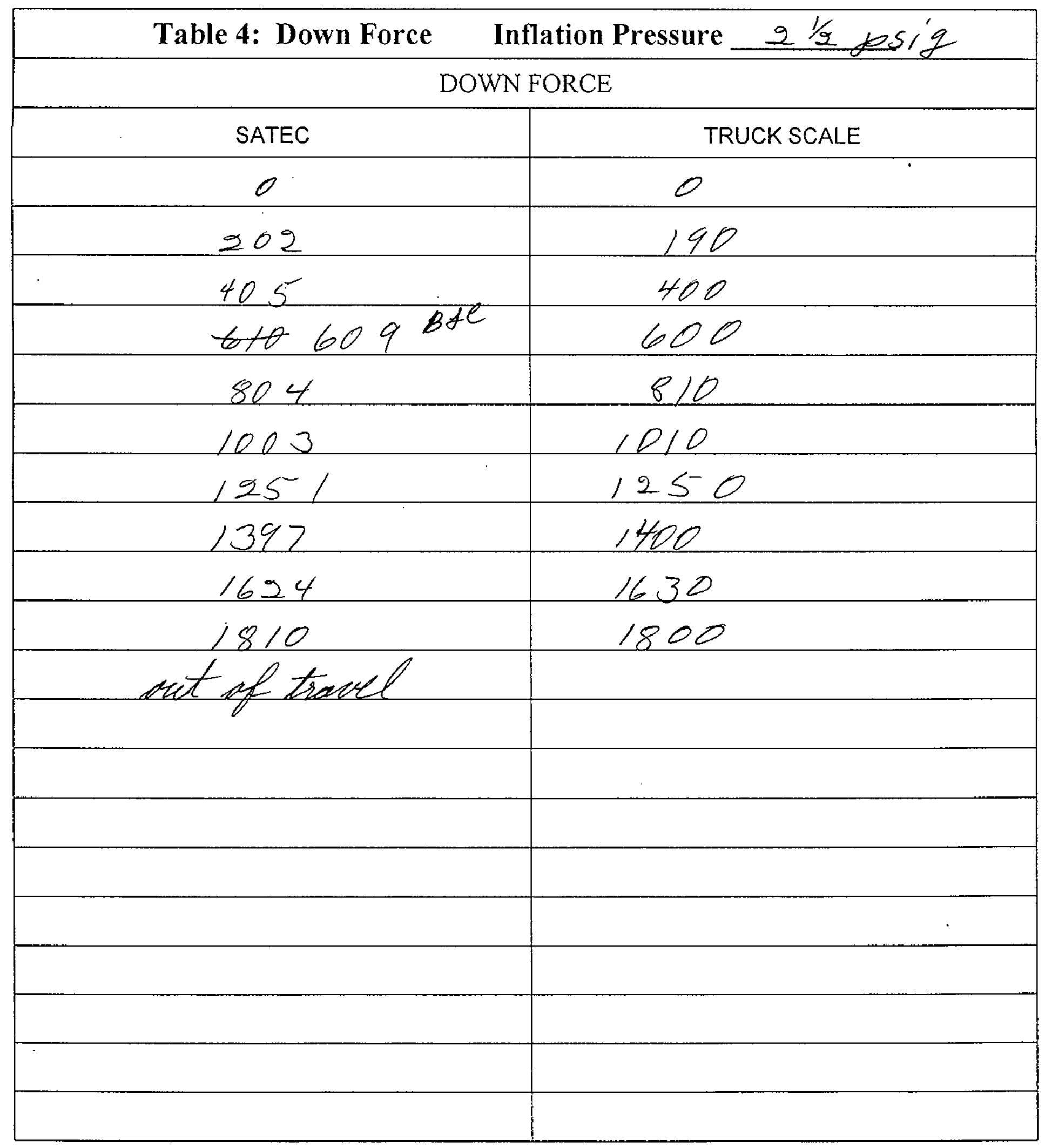

A-3000-723 (01/98)

Page B-14 
HNF-4389, Rev. 0

$\# 10$

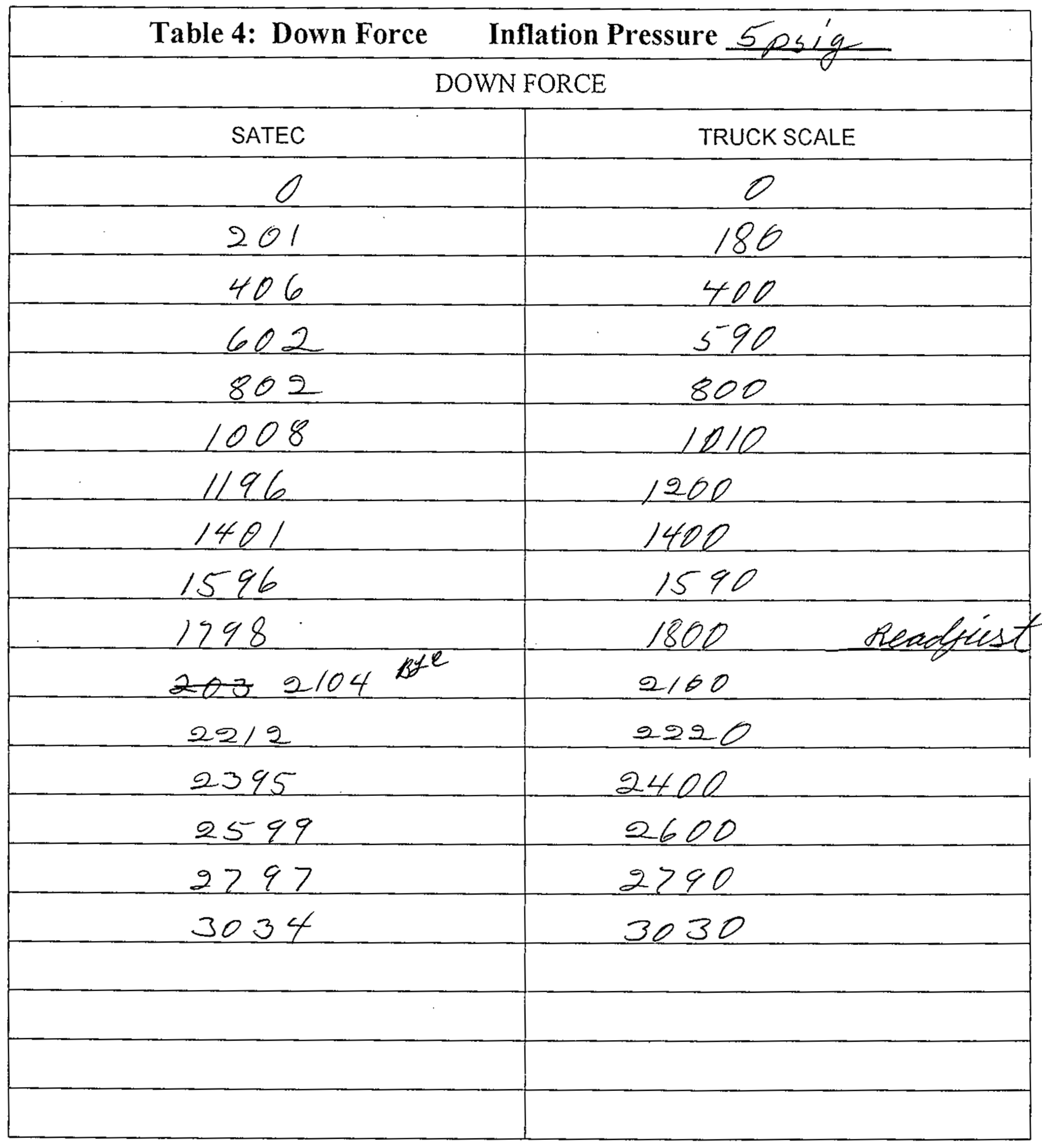

A-3000-723 (01/98)

Page B-15 
HNF-4389, Rev. 0

\#/1

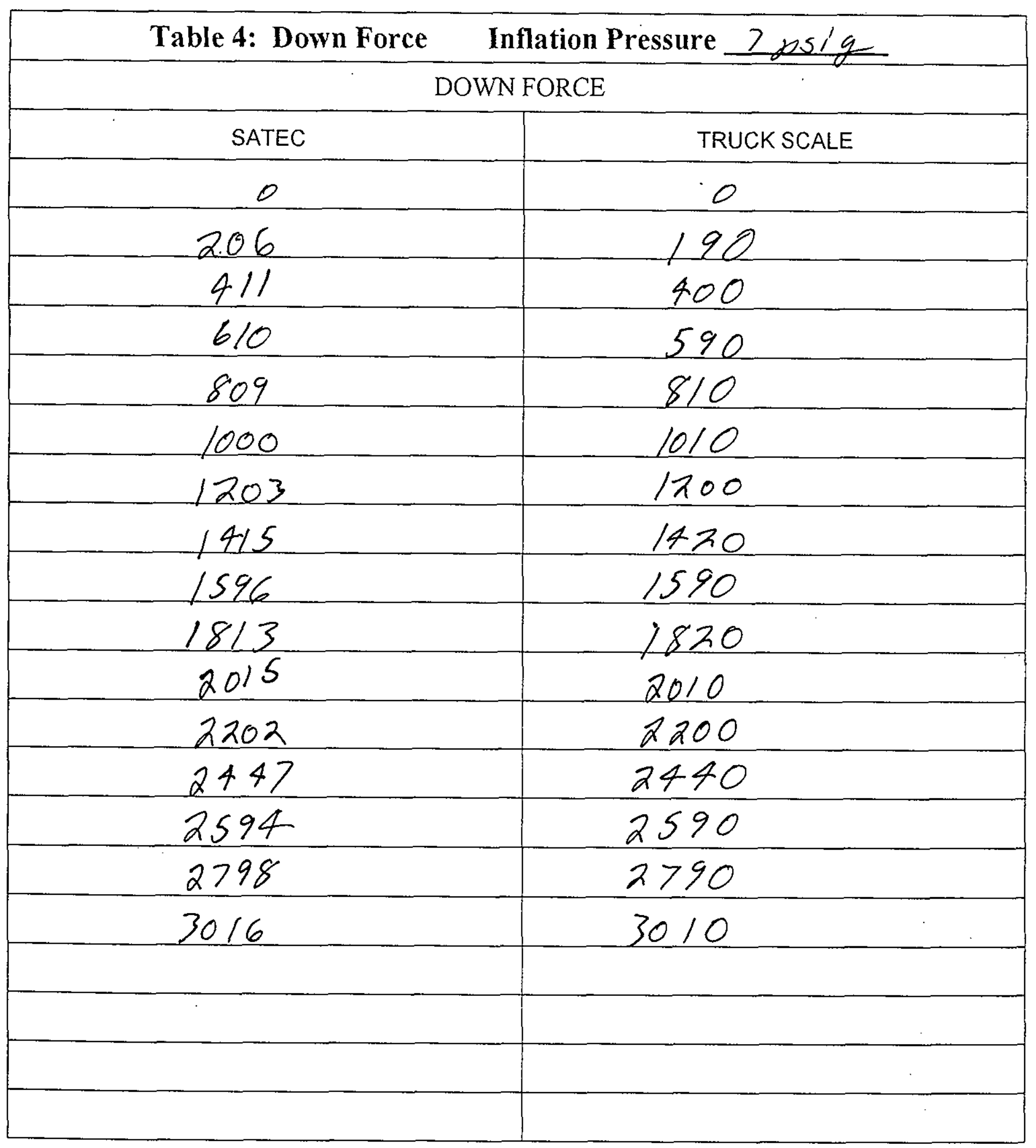

A-3000-723 (01/98)

Page B-16 
Table 4: Down Force Inflation Pressure $2^{1 / 2}$ DOWN FORCE

\begin{tabular}{|c|c|}
\hline SATEC & TRUCK SCALE \\
\hline 2 & 0 \\
\hline 206 & 200 \\
\hline 406 & 400 \\
\hline 610 & 590 \\
\hline 832 & 1030 \\
\hline 1020 & 1200 \\
\hline 1202 & 1400 \\
\hline 1627 & 180 \\
\hline 1817 & \\
\hline & \\
\hline
\end{tabular}


HNF-4389, Rev. 0

$\# 13$

\begin{tabular}{|c|c|}
\hline \multicolumn{2}{|c|}{ Table 4: Down Force Inflation Pressure } \\
\hline \multicolumn{2}{|c|}{ DOWN FORCE } \\
\hline SATES & TRUCK SCALE \\
\hline 8 & 0 \\
\hline 202 & 170 \\
\hline 404 & 390 \\
\hline 40 & 590 \\
\hline 800 & 790 \\
\hline 994 & 1000 \\
\hline 1199 & 1200 \\
\hline 1439 & 1430 \\
\hline 1608 & 1600 \\
\hline 1824 & 1820 \\
\hline 2020 & 2010 \\
\hline 2219 & 2210 \\
\hline 2393 & 2390 \\
\hline 2632 & 2632 \\
\hline 2834 & 2830 \\
\hline 3006 & 3000 \\
\hline & \\
\hline & \\
\hline & \\
\hline & \\
\hline
\end{tabular}

A-3000-723 (01/98)

Page B-18 
HNF-4389, Rev. 0

$\# 14$

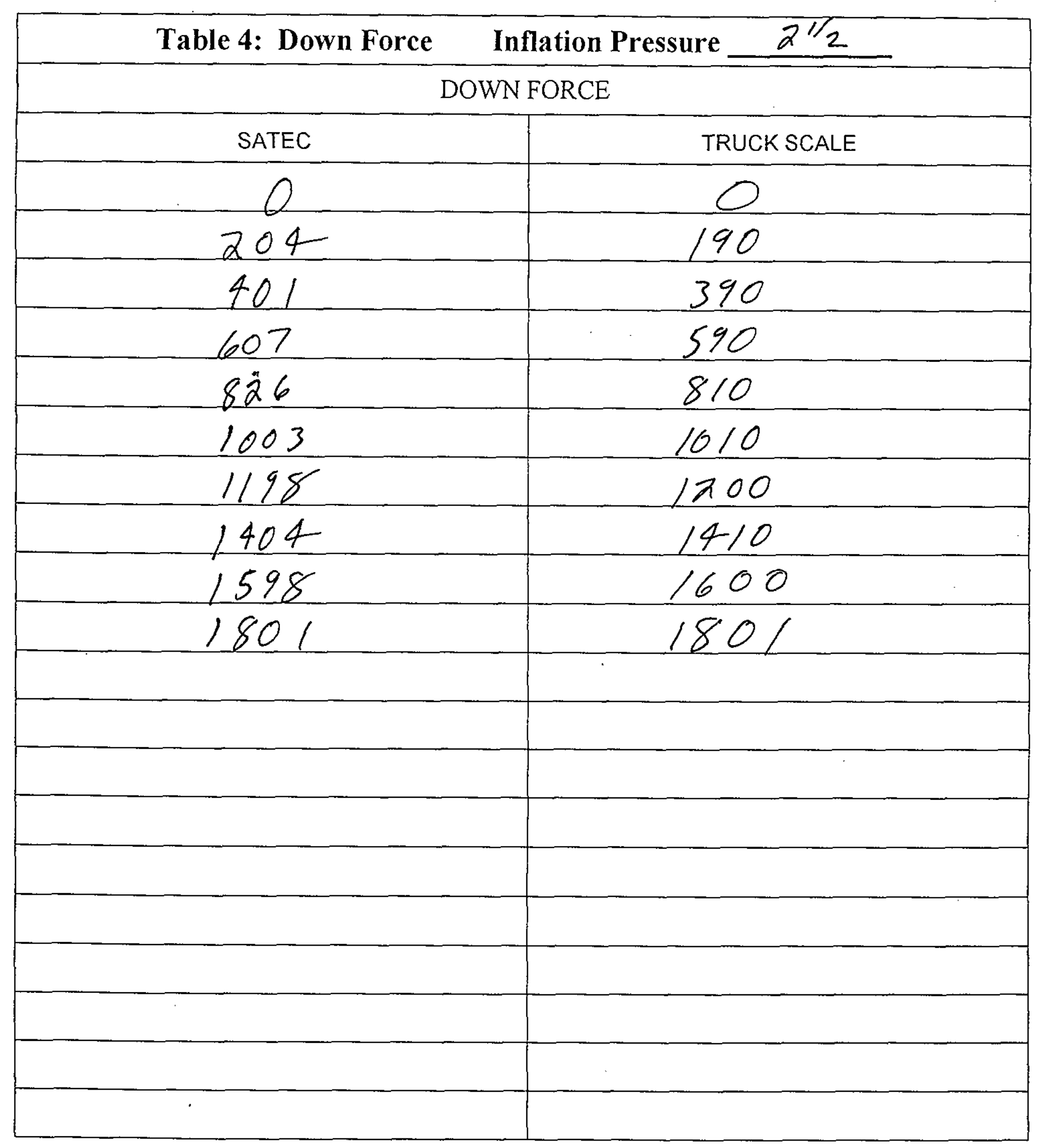

A-3000-723 (01/98)

Page B-19 
$\# 15$

HNF-4389, Rev. 0

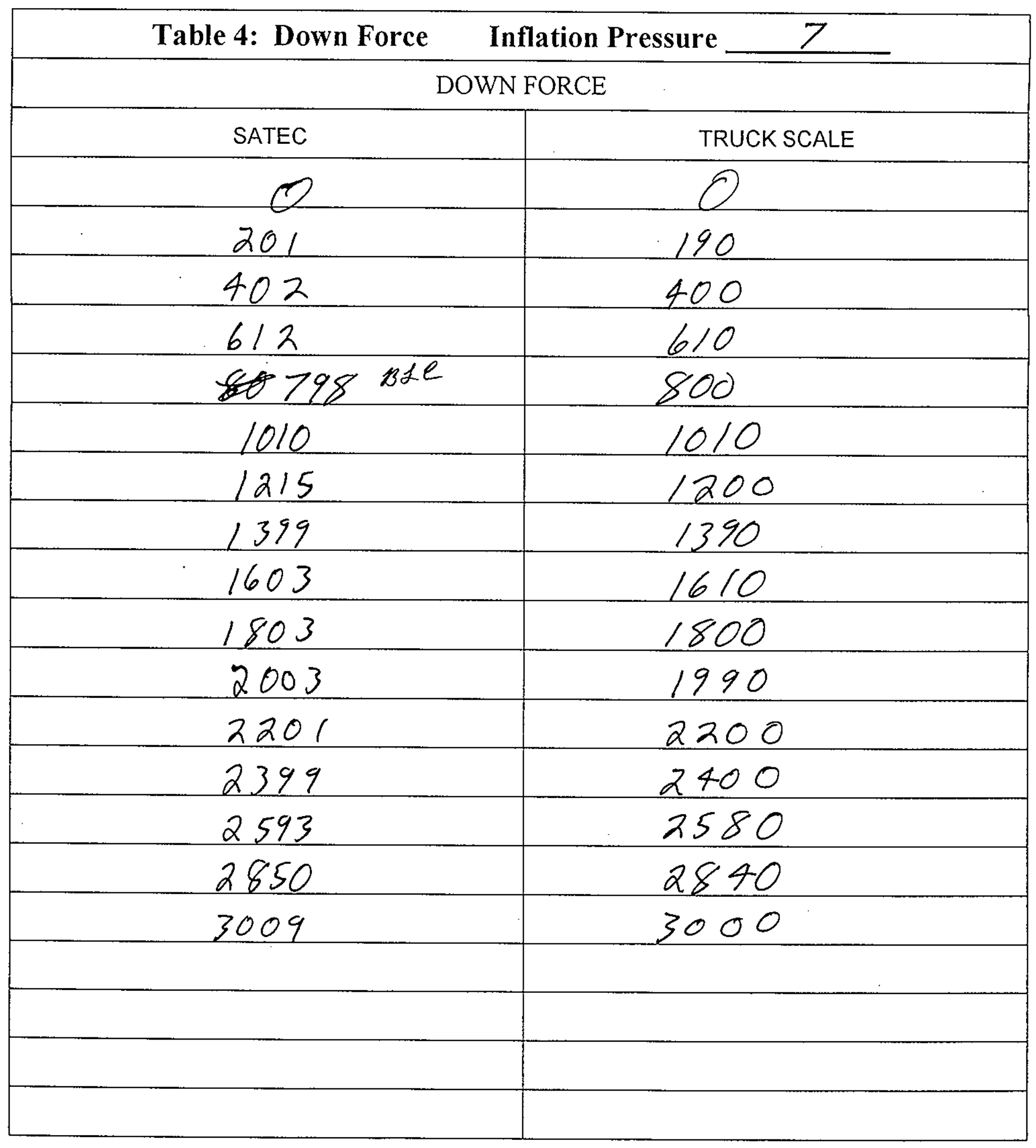

A-3000-723 (01/98)

Page B-20 
HNF-4389, Rev. 0

APPENDIX C: TEST DATA AND CALCULATIONS

Page $\mathrm{C}-1$ 
HNF-4389, Rev. 0

TABLE 1

Truck Scale

SATEC Difference

0

190

188

370

392

590

591

800

801

1010

1200

1410

1610

1820

2010

2200

2400

992

1201

1409

1599

1805

1994

2199

2389

2600

2586

2810

2797

3000

2994

\section{Deviation}

2

2
-22

$-1$

$-1$

18

$-1$

1

11

15

16

1

11

14

13

6
Standard Deviation 10.03

2

22 Maximum Deviation

22

Minimum Deviation

0 
HNF-4389, Rev. 0

Test \#2 @ 5 psig.

Truck Scale

(Ib.)

90

90

Test \#2 @ 5 psig. (Repeat)

Truck Scale

(lb.)

60

60

60

60

60

60

60
SATEC

(Ib.)

N/A

N/A

SATEC

(Ib.)

80

80

80

80

80

80

80
Distance

(in.)

$91 / 4$

$1715 / 16$
Distance

(in.)

8

10

12

14

16

18

19

Page C-3 
HNF-4389, Rev. 0

Standard Deviation (all tests) 10.20

Maximum Standard Deviation 14.33

Minimum Standard Deviation

6.32

Test Number

Sheet\#1

2.5 psig

5 psig

Sheet \#3

7 psig
Maximum Deviation

40.00

Minimum Deviation

1.00 0
193

384

585

784

987

1222

1391

1591

1789

0

195

394

588

788

989

1188

1395

1588

1783

1978

2185

2391

2612

2802

2977

197

390

600

796

986

1197

1390

1570

1785

1990

2186

2390

2575

2800

2995

$\begin{array}{rr}\text { Truck Scale } & \\ & \\ 180 \\ 370 \\ 570 \\ 790 \\ 1010 \\ 1240 \\ 1400 \\ 1610 \\ 1800\end{array}$

Difference

0

13

14

15

$-6$

$-23$

$-18$

$-9$

$-19$

$-11$

0

15

24

370

580

780

1000

1190

1380

1590

1790

1980

2190

2390

2640

2810

2990

0

190

380

600

800

1000

1190

1430

1590

1790

1990

2190

2390

2580

2800

2990

$-13$

0

10

0

$-4$

$-14$

7

$-40$

$-20$

$-5$

0

$-4$

$-5$

0

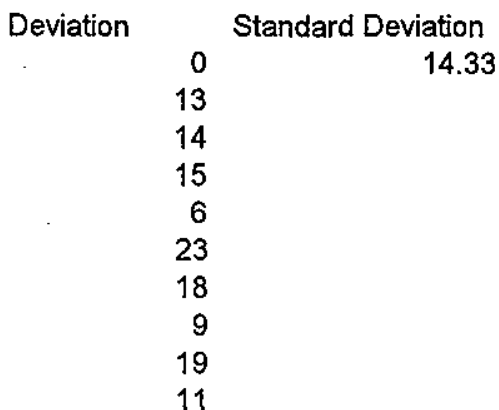

12.59

15

24

8

8
11

2

15

2

2

5

1

28

8

13

0

0
7
10
0
4
14
7
40
20
5
0
4
0
5
0
5

12.26 
HNF-4389, Rev. 0

Test Number

Sheet \#4

7 psig

Sheet \#5

2.5 psig

Sheet \#6

5 psig
SATEC

Truck Scale

Difference

Deviation

Standard Deviation

180

370

580

790

1000

1190

1380

1590

1790

1980

2190

2390

2580

2790

2980

0
170

370

570

780

990

1220

1390

1580

1790

1590

1780

0

195

392

594

794

1000

1196

1440

1668

1780

2003

2203

2402

2615

2805

3020
0

180

390

590

810

1010

1200

1460

1670

1800

2000

2210

2400

2610

2810

3015

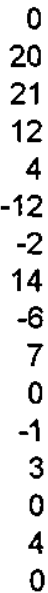

0
20
21
12
4
-12
-2
14
-6
7
0
-1
3
0
4
0

$0 \quad 0$

24

22

20

8

$-12$

0

0

10

$-10$

0

15

2

$-16$

$-10$

$-4$

$-20$

$-2$

$-20$

3

$-7$

2

5

$-5$

5
8.94

12.84

24

22

20

8

12

0

0

10

10

0

0
15

15

2

4

16

10

4

20

2

20

3

7

2

5

5

5 
HNF-4389, Rev. 0

\begin{tabular}{|c|c|c|c|c|c|}
\hline Test Number & SATEC & Truck Scale & Difference & Deviation & Standard Deviation \\
\hline Sheet \#7 & 0 & 0 & 0 & 0 & 6.52 \\
\hline \multirow[t]{15}{*}{$7 \mathrm{psig}$} & 204 & 200 & 4 & 4 & \\
\hline & 400 & 400 & 0 & 0 & \\
\hline & 602 & 590 & 12 & 12 & \\
\hline & 803 & 810 & -7 & 7 & \\
\hline & 985 & 1000 & -15 & 15 & \\
\hline & 1202 & 1200 & 2 & 2 & \\
\hline & 1400 & 1400 & 0 & 0 & \\
\hline & 1604 & 1610 & -6 & 6 & \\
\hline & 1800 & 1800 & 0 & 0 & \\
\hline & 2003 & 2010 & -7 & 7 & \\
\hline & 2239 & 2230 & 9 & 9 & \\
\hline & 2398 & 2400 & -2 & 2 & \\
\hline & 2597 & 2600 & -3 & 3 & \\
\hline & 2805 & 2810 & -5 & 5 & \\
\hline & 3003 & 3000 & 3 & 3 & \\
\hline Sheet \#8 & 0 & 0 & 0 & 0 & 6.32 \\
\hline \multirow{15}{*}{$5 \mathrm{psig}$} & 204 & 190 & 14 & 14 & \\
\hline & 400 & 390 & 10 & 10 & \\
\hline & 598 & 590 & 8 & 8 & \\
\hline & 806 & 810 & -4 & 4 & \\
\hline & 1006 & 1010 & -4 & 4 & \\
\hline & 1217 & 1220 & -3 & 3 & \\
\hline & 1421 & 1420 & 1 & 1 & \\
\hline & 1609 & 1610 & -1 & 1 & \\
\hline & 1813 & 1800 & 13 & 13 & \\
\hline & 2008 & 2010 & -2 & 2 & \\
\hline & 2195 & 2190 & 5 & 5 & \\
\hline & 2397 & 2400 & -3 & 3 & \\
\hline & 2597 & 2600 & -3 & 3 & \\
\hline & 2805 & 2800 & 5 & 5 & \\
\hline & 3009 & 3000 & 9 & 9 & \\
\hline Sheet \#9 & 0 & 0 & 0 & 0 & 7.14 \\
\hline \multirow{9}{*}{$2.5 \mathrm{psig}$} & 202 & 190 & 12 & 12 & \\
\hline & 405 & 400 & 5 & 5 & \\
\hline & 609 & 600 & 9 & 9 & \\
\hline & 804 & 810 & -6 & 6 & \\
\hline & 1003 & 1010 & -7 & 7 & \\
\hline & 1251 & 1250 & 1 & 1 & \\
\hline & 1397 & 1400 & -3 & 3 & \\
\hline & 1624 & 1630 & -6 & 6 & \\
\hline & 1810 & 1800 & 10 & 10 & \\
\hline
\end{tabular}


HNF-4389, Rev. 0

\begin{tabular}{|c|c|c|c|c|c|}
\hline Test Number & SATEC & Truck Scale & Difference & Deviation & Standard Deviation \\
\hline Sheet \#10 & 0 & 0 & 0 & 0 & 7.08 \\
\hline \multirow[t]{15}{*}{5 psig } & 201 & 180 & 21 & 21 & \\
\hline & 406 & 400 & 6 & 6 & \\
\hline & 602 & 590 & 12 & 12 & \\
\hline & 802 & 800 & 2 & 2 & \\
\hline & 1008 & 1010 & -2 & 2 & \\
\hline & 1196 & 1200 & -4 & 4 & \\
\hline & 1401 & 1400 & 1 & 1 & \\
\hline & 1596 & 1590 & 6 & 6 & \\
\hline & 1798 & 1800 & -2 & 2 & \\
\hline & 2104 & 2100 & 4 & 4 & \\
\hline & 2212 & 2220 & -8 & 8 & \\
\hline & 2395 & 2400 & -5 & 5 & \\
\hline & 2599 & 2600 & -1 & 1 & \\
\hline & 2797 & 2790 & 7 & 7 & \\
\hline & 3034 & 3030 & 4 & 4 & \\
\hline Sheet \#11 & 0 & 0 & 0 & 0 & 7.86 \\
\hline \multirow[t]{15}{*}{7 psig } & 206 & 190 & 16 & 16 & \\
\hline & 411 & 400 & 11 & 11 & \\
\hline & 610 & 590 & 20 & 20 & \\
\hline & 809 & 810 & -1 & 1 & \\
\hline & 1000 & 1010 & -10 & 10 & \\
\hline & 1203 & 1200 & 3 & 3 & \\
\hline & 1415 & 1420 & -5 & 5 & \\
\hline & 1596 & 1590 & 6 & 6 & \\
\hline & 1813 & 1820 & -7 & 7 & \\
\hline & 2015 & 2010 & 5 & 5 & \\
\hline & 2202 & 2200 & 2 & 2 & \\
\hline & 2447 & 2440 & 7 & 7 & \\
\hline & 2594 & 2590 & 4 & 4 & \\
\hline & 2798 & 2790 & 8 & 8 & \\
\hline & 3016 & 3010 & 6 & 6 & \\
\hline Sheet \#12 & 0 & 0 & 0 & 0 & 11.82 \\
\hline \multirow[t]{9}{*}{$2.5 \mathrm{psig}$} & 206 & 200 & 6 & 6 & \\
\hline & 406 & 400 & 6 & 6 & \\
\hline & 610 & 590 & 20 & 20 & \\
\hline & 862 & 830 & 32 & 32 & \\
\hline & 1020 & 1010 & 10 & 10 & \\
\hline & 1202 & 1200 & 2 & 2 & \\
\hline & 1393 & 1400 & -7 & 7 & \\
\hline & 1627 & 1610 & 17 & 17 & \\
\hline & 1817 & 1820 & -3 & 3 & \\
\hline
\end{tabular}


HNF-4389, Rev. 0

\begin{tabular}{|c|c|c|c|c|c|}
\hline Test Number & SATEC & Truck Scale & Difference & Deviation & Standard Deviation \\
\hline Sheet\#13 & 0 & 0 & 0 & 0 & 9.05 \\
\hline \multirow[t]{16}{*}{5 psig } & 202 & 170 & 32 & 32 & \\
\hline & 404 & 390 & 14 & 14 & \\
\hline & 610 & 590 & 20 & 20 & \\
\hline & 800 & 790 & 10 & 10 & \\
\hline & 994 & 1000 & -6 & 6 & \\
\hline & 1199 & 1200 & -1 & 1 & \\
\hline & 1439 & 1430 & 9 & 9 & \\
\hline & 1608 & 1600 & 8 & 8 & \\
\hline & 1824 & 1820 & 4 & 4 & \\
\hline & 2020 & 2010 & 10 & 10 & \\
\hline & 2219 & 2210 & 9 & 9 & \\
\hline & 2393. & 2390 & 3 & 3 & \\
\hline & 2632 & 2632 & 0 & 0 & \\
\hline & 2834 & 2830 & 4 & 4 & \\
\hline & 3006 & 3000 & 6 & 6 & \\
\hline & & & & 0 & \\
\hline Sheet \#14 & 0 & 0 & 0 & 0 & 9.35 \\
\hline \multirow[t]{9}{*}{2.5 psig } & 204 & 190 & 14 & 14 & \\
\hline & 401 & 390 & 11 & 11 & \\
\hline & 607 & 590 & 17 & 17 & \\
\hline & 826 & 810 & 16 & 16 & \\
\hline & 1003 & 1010 & -7 & 7 & \\
\hline & 1198 & 1200 & -2 & 2 & \\
\hline & 1404 & 1410 & -6 & 6 & \\
\hline & 1598 & 1600 & -2 & 2 & \\
\hline & 1801 & 1801 & 0 & 0 & \\
\hline Sheet \#15 & 0 & 0 & 0 & 0 & 6.52 \\
\hline \multirow[t]{15}{*}{7 psig } & 201 & 190 & 11 & 11 & \\
\hline & 402 & 400 & 2 & 2 & \\
\hline & 612 & 610 & 2 & 2 & \\
\hline & 798 & 800 & -2 & 2 & \\
\hline & 1010 & 1010 & 0 & 0 & \\
\hline & 1215 & 1200 & 15 & 15 & \\
\hline & 1399 & 1390 & 9 & 9 & \\
\hline & 1603 & 1610 & -7 & 7 & \\
\hline & 1803 & 1800 & 3 & 3 & \\
\hline & 2003 & 1990 & 13 & 13 & \\
\hline & 2201 & 2200 & 1 & 1 & \\
\hline & 2399 & 2400 & -1 & 1 & \\
\hline & 2593 & 2580 & 13 & 13 & \\
\hline & 2850 & 2840 & 10 & 10 & \\
\hline & 3009 & 3000 & 9 & 9 & \\
\hline
\end{tabular}


HNF-4389, Rev. 0

APPENDIX D: DOWN FORCE CALIBRATION STAND TEST PROCEDURE

Page D-1 
HNF-4389, Rev. 0

\section{DOWN FORCE CALIBRATION STAND TEST PROCEDURE}

By: B. L. Coverdell

COGEMA Engineering Corporation

March 19, 1999

Page D-2 


\section{TABLE OF CONTENTS}

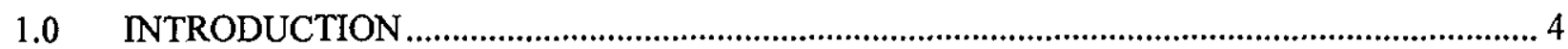

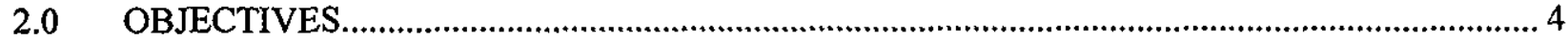

3.0 SAFETY

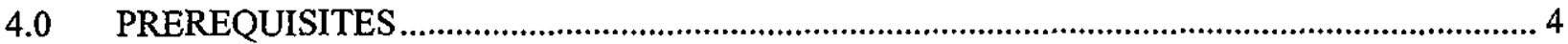

5.0 TEST …

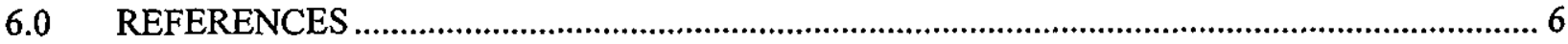




\subsection{INTRODUCTION}

This procedure provides instruction for verifying that the Down Force Calibration Stand operates correctly and to verify that the combination of Down Force Calibration Stand and Core Sample Truck function together properly.

\subsection{OBJECTIVES}

This procedure verifies the adequacy of the Down Force Calibration Stand to be used as a tool for calibration of down force on Core Sample Trucks \#3 \& \#4. The optimum bellows inflation pressure shall also be verified.

\subsection{SAFETY}

3.1 Ensure the pressure relief valve has been set to $90 \mathrm{psi}$.

3.2 This test to be performed in the dean dome only.

3.3 Ensure that bellows does not bottom out during test.

3.4 If pressure relief valve vents, discontinue this test immediately and notify Dave Haring.

\subsection{PREREQUISITES}

\subsection{Special Tools, Equipment and Supplies}

The following equipment is needed to perform this test:

[ ] Down Force Calibration Stand.

[ ] Approximately 50 lbs of verified weights

[ ] Core Sample Trucks 3 or 4 (with recent down force calibration).

[ ] Air Compressor.

[ ] Portable Scale, 0 to $5000 \mathrm{lb}$. minimum, calibrated.

\subsection{Performance Documents}

[ ] TO-080-518, Core Sampling With Trucks $3 \& 4$ (Rotary Bit)

[ ] TO-080-519, Core Sampling With Trucks $3 \& 4$ (Push Bit) 
5.1 Verify Transmission of Down Force to Scale as follows:

5.1.1 OPEN pressure gauge isolation valve, $\mathrm{V}-1$.

5.1.2 ADD/BLEED air from bellows until pressure gauge, $\mathrm{P}-1$, indicates $5.0 \mathrm{psig}$ to 6.0 psig. Record this pressure in the location provided in Table-1. NOTE: This pressure may be varied at the engineer's discretion.

5.1.3 CLOSE pressure gauge isolation valve, $\mathrm{V}-1$.

5.1.4 ADD approximately $50 \mathrm{lbs}$ of verified weight to the Down Force Calibration Stand upper bearing plate. NOTE: Exact placement of weight and total applied weight shall be at the engineer's discretion.

5.1.5 RECORD the weight of the verified weight. Record this data in Table 1.

5.1.6 RECORD the as read from the portable scale. Record this data in Table-1.

5.1.7 DISCONTINUE test if portable scale reads $\pm 10 \mathrm{lbs}$ more than the verified weights.

5.2 Prepare Down Force Calibrations stand for $3000 \mathrm{lb}$. load test as follows:

5.2.1 OPEN pressure gauge isolation valve, $\mathrm{V}-1$.

5.2.2 ADD/BLEED air from bellows until pressure gauge, $\mathrm{P}-1$, indicates $5.0 \mathrm{psig}$ to 6.0 psig. Record this pressure in location provided in Table-2. NOTE: This pressure may be varied at the engineer's discretion.

5.2.3 CLOSE pressure gauge isolation valve, $\mathrm{V}-1$.

5.2.4 APPLY down force at greater than $3 / 4$ " of an inch per minute.

5.2.5 RECORD the down force (as read from the portable scale and weight indicator 1) and the deflection every $100 \mathrm{lbs}$. up to $2000 \mathrm{lbs}$. And every $500 \mathrm{lbs}$. up to 3000 lbs. Record this data in Table-2.

5.2.6 Return RAM to full up position.

5.3 Prepare Down Force Calibrations stand for $1200 \mathrm{lb}$. rotary mode load test as follows:

5.3.1 OPEN pressure gauge isolation valve, $\mathrm{V}-1$.

5.3.2 ADD/BLEED air from bellows until pressure gauge, $\mathrm{P}-1$, indicates 5.0 psig to $6.0 \mathrm{psig}$. Record this pressure in location provided in Table-3. NOTE: This pressure may be varied at the engineer's discretion.

5.3.3 CLOSE pressure gauge isolation valve, $\mathrm{V}-1$.

5.3.4 APPLY down force at greater than $3 / 4$ " of an inch per minute. 
HNF-4389, Rev. 0

5.3.5 RECORD the down force (as read from the portable scale and weight indicator 1) and the deflection every $100 \mathrm{lbs}$. up to $1200 \mathrm{lbs}$. Record this data in Table-3.

\subsubsection{Return RAM to full up position}

\subsection{REFERENCES}

Drawing H-2-690124, Down Force Calibration Stand Assembly, H-2-690125 Rev. 0, COGEMA Engineering Corporation, Richland, Washington. 
HNF-4389, Rev. 0

Table 1: Down Force and Deflection

\section{Inflation Pressure}

DOWN FORCE (lbs.)

VERIFIED WEIGHTS

PORTABLE SCALE

Table 1: Down Force and Deflection

Inflation Pressure

DOWN FORCE (lbs.)

VERIFIED WEIGHTS

PORTABLE SCALE 
HNF-4389, Rev. 0

Table 2: Down Force and Deflection DOWN FORCE (lbs.) PORTABLE SCALE
WI-1

\section{Inflation Pressure}

DEFLECTION

(in.)

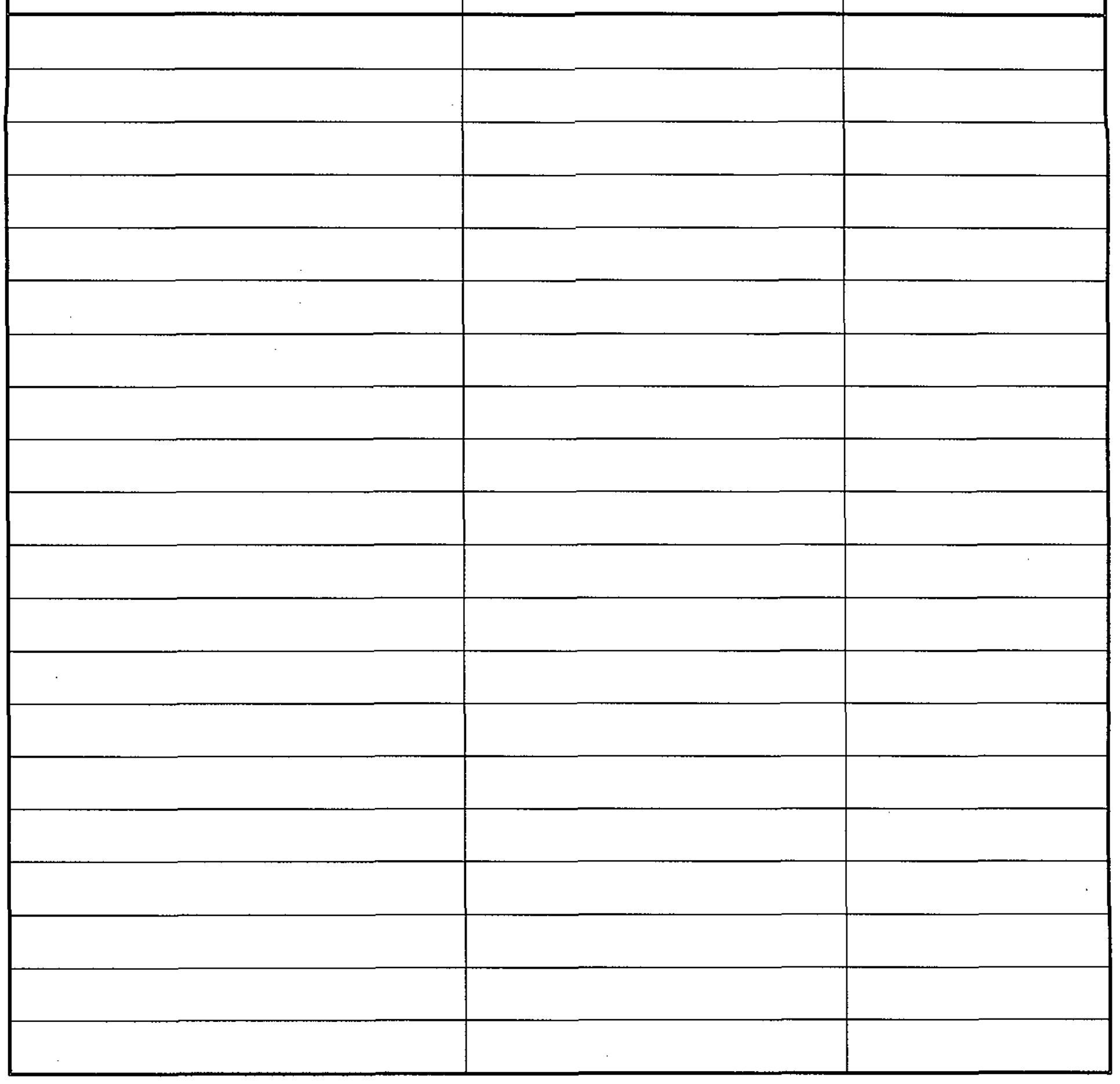




\section{Table 3: Rotary Mode Down Force and Deflection Inflation Pressure}

\section{DOWN FORCE (lbs.)}

PORTABLE SCALE
WI-1
DEFLECTION

(in.) 
HNF-4389, Rev. 0

APPENDIX E: TEST PROCEDURE DATA SHEETS

Page E-1 
HNF-4389, Rev. 0

Table 1: Down Force and Deflection

Inflation Pressure 425 psig

DOWN FORCE (lbs.)

VERIFIED WEIGHTS

PORTABLE SCALE :

$50^{*}$ he $3 / 18 / 99$

so \# bye $3 / 18 / 99$

Table 1: Down Force and Deflection

Inflation Pressure 4,25 psig

DOWN FORCE (lbs.)

VERIFIED WEIGHTS

$70^{\#}$
Bje $3 / 18 / 99$
PORTABLE SCALE

$20^{\not t}$ Boe 3/18/99 
HNF-4389, Rev. 0

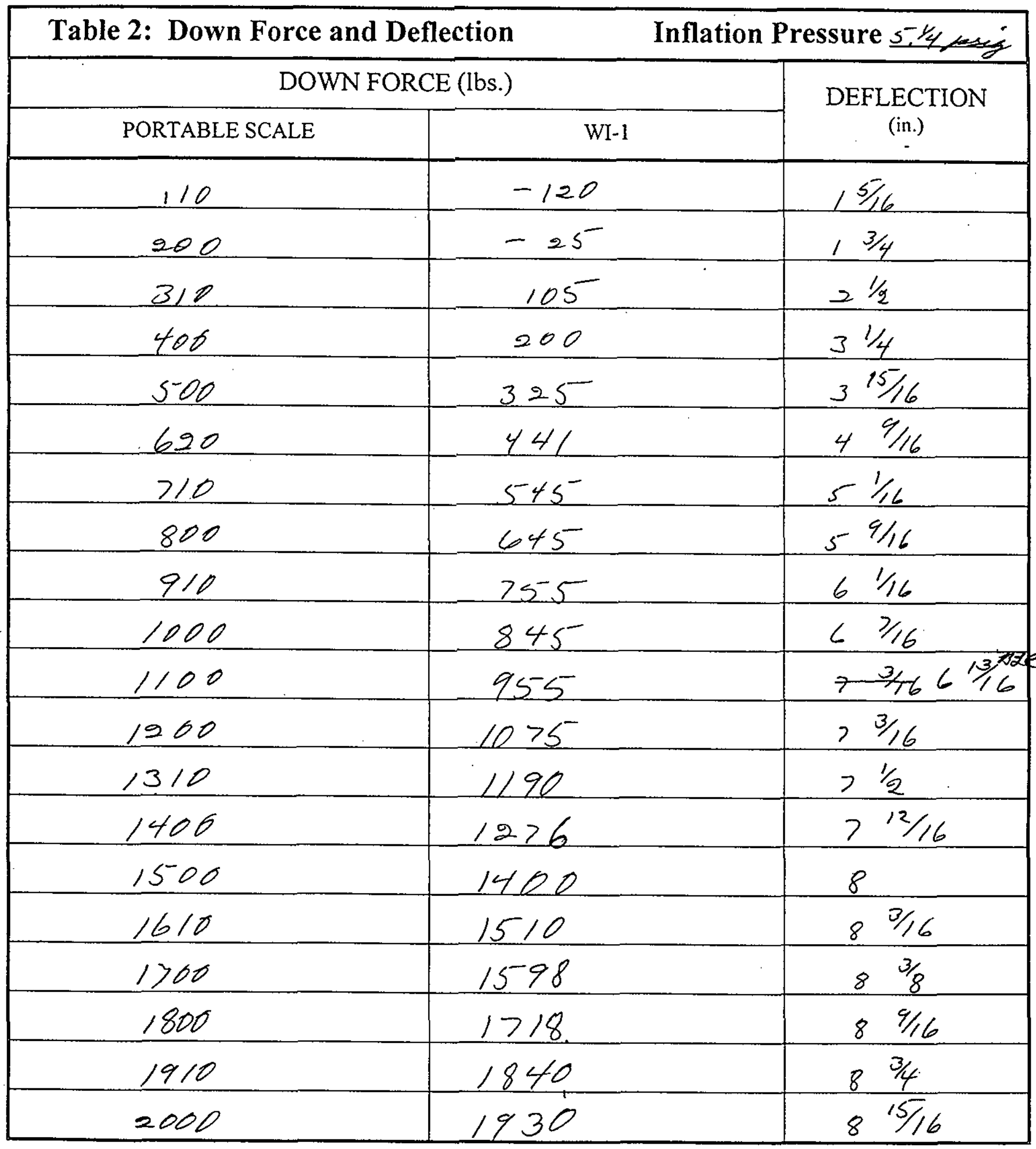

Page E-3 


\section{Table 2: Down Force and Deflection (cont.) Inflation Pressure 51/4 psig}

\section{DOWN FORCE (lbs.)}

PORTABLE SCALE

2510

3010
WI-1

$2475^{-}$

2990
DEFLECTION

(in.)

$95 / 8$
$10 \% 4$


HNF-4389, Rev. 0

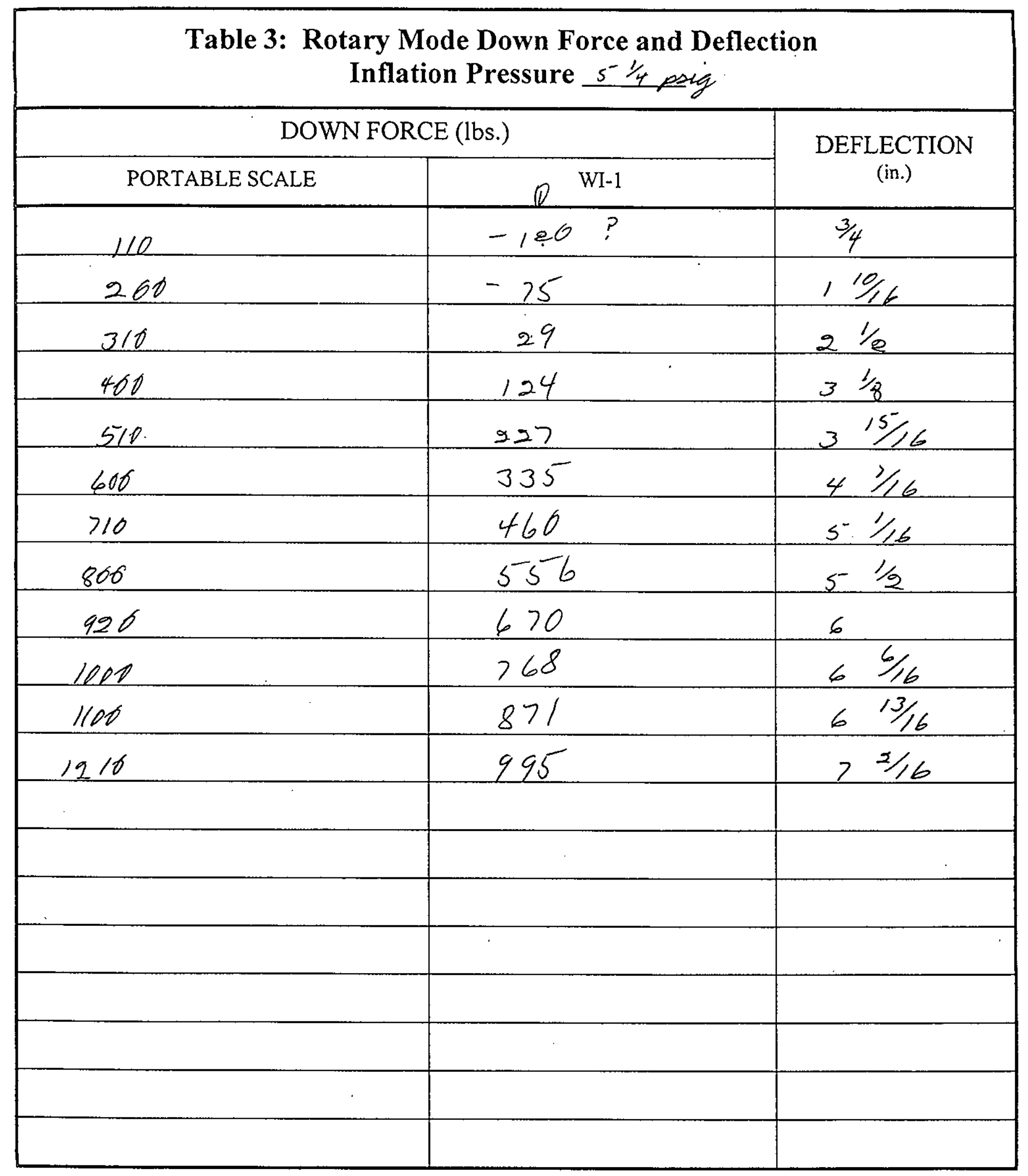

Page E-5 